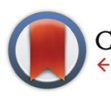

CrossMark

Cite this: Dalton Trans., 2015, 44, 8564

Received 4th November 2014 Accepted 4th February 2015

DOI: $10.1039 / \mathrm{c} 4 \mathrm{dt} 03378 \mathrm{~g}$

www.rsc.org/dalton

\title{
Iridium(III) N-heterocyclic carbene complexes: an experimental and theoretical study of structural, spectroscopic, electrochemical and electrogenerated chemiluminescence properties $\uparrow$
}

\author{
Gregory J. Barbante, ${ }^{a}$ Egan H. Doeven, ${ }^{a}$ Paul S. Francis, ${ }^{a}$ Bradley D. Stringer, ${ }^{b}$ \\ Conor F. Hogan, ${ }^{\star b}$ Peyman R. Kheradmand, ${ }^{b}$ David J. D. Wilson ${ }^{b}$ and \\ Peter J. Barnard*b
}

\begin{abstract}
Four cationic heteroleptic iridium(III) complexes have been prepared from methyl- or benzyl-substituted chelating imidazolylidene or benzimidazolylidene ligands using a Ag(I) transmetallation protocol. The synthesised iridium(III) complexes were characterised by elemental analysis, ${ }^{1} \mathrm{H}$ and ${ }^{13} \mathrm{C}$ NMR spectroscopy and the molecular structures for three complexes were determined by single crystal $\mathrm{X}$-ray diffraction. A combined theoretical and experimental investigation into the spectroscopic and electrochemical properties of the series was performed in order to gain understanding into the factors influencing photoluminescence and electrochemiluminescence efficiency for these complexes, with the results compared with those of similar $\mathrm{NHC}$ complexes of iridium and ruthenium. The $\mathrm{N}^{\wedge} \mathrm{C}$ coordination mode in these complexes is thought to stabilise thermally accessible non-emissive states relative to the case with analogous complexes with $\mathrm{C}^{\wedge} \mathrm{C}$ coordinated $\mathrm{NHC}$ ligands, resulting in low quantum yields. As a result of this and the instability of the oxidised and reduced forms of the complexes, the electrogenerated chemiluminescence intensities for the compounds are also low, despite favourable energetics. These studies provide valuable insights into the factors that must be considered when designing new NHCbased luminescent complexes.
\end{abstract}

\section{Introduction}

Providing a versatile synthetic framework and fine control of electronic properties, $\mathrm{N}$-heterocyclic carbenes (NHC) are emerging as a useful option for the development of novel luminescent materials. ${ }^{1-4}$ In recent years, luminescent complexes of metals such as $\mathrm{Cu}(\mathrm{I}),{ }^{5,6} \mathrm{Ag}(\mathrm{I}),{ }^{7,8} \mathrm{Au}(\mathrm{I}),{ }^{7,9-12} \mathrm{Ni}(\mathrm{II}),{ }^{13} \mathrm{Pd}(\mathrm{II}),{ }^{13,14}$ $\mathrm{Pt}(\mathrm{II}),{ }^{13-17} \mathrm{Ir}(\mathrm{III}),{ }^{18-21} \mathrm{Ru}(\mathrm{II}),{ }^{22-27} \mathrm{Os}(\mathrm{II}),{ }^{28} \mathrm{Re}(\mathrm{I}),{ }^{29,30} \mathrm{Zr}(\mathrm{IV}),{ }^{31}$ and $\mathrm{Hf}(\mathrm{Iv}),{ }^{31}$ incorporating NHC ligands have been devised for a wide range of fundamental investigations, photoluminescence applications and light-emitting devices. Similarly, NHC

\footnotetext{
${ }^{a}$ Centre for Chemistry and Biotechnology, School of Life and Environmental Sciences, Faculty of Science, Engineering and Built Environment, Deakin University, Geelong, Victoria 3216, Australia

${ }^{b}$ Department of Chemistry, La Trobe Institute for Molecular Science, La Trobe University, Melbourne, Victoria 3086, Australia.E-mail: p.barnard@latrobe.edu.au, c.hogan@latrobe.edu.au

$\dagger$ Electronic supplementary information (ESI) available: X-ray crystallography data, molecular orbital analysis and plots, TD-DFT calculated absorption spectra. CCDC 1031786-1031788. For ESI and crystallographic data in CIF or other electronic format see DOI: $10.1039 / \mathrm{c} 4 \mathrm{dt} 03378 \mathrm{~g}$
}

ligands have recently been exploited to manipulate the electrochemical and spectroscopic properties of metal complexes for electrogenerated chemiluminescence (also known as electrochemiluminescence or ECL). ${ }^{26,32,33}$ In a typical ECL reaction, the complex is electrochemically oxidised before receiving an electron from a strong reductant to generate its electronically excited state. $^{34-42}$

ECL can be separated into two operational modes that are distinguished by the source of the reductant; in annihilation ECL it is derived from electrochemical reduction of the metal complex itself, whereas in co-reactant ECL it is formed by the concurrent oxidation of a sacrificial reagent such as tri- $n$-propylamine (TPA). While the latter is important for the development highly sensitive analytical applications, the importance of the former lies in the insights that can be gained into the design and operation of light emitting devices (LEDs), in particular light emitting electrochemical cells (LECs). Control of the electronic properties of each ligand of a complex allows tuning of not only the energetics of the reactions required to generate the excited species, but also the emission colour. This is of great interest for the development of mixed metal- 
complex ECL systems ${ }^{43-46}$ for multiplexed analysis in the case of co-reactant ECL; or for colour tuneable LEDs in the case of annihilation ECL.

We have previously examined the electrochemical, photoluminescence and ECL properties of four Ru(II) complexes that each contain two bipyridine (bpy) ligands and a pyridinefunctionalised imidazoylidene- or benzimidazolylidene-NHC ligand (5-8 in Scheme 1a). ${ }^{32}$ Compared to the benchmark ECL emitter $\left[\mathrm{Ru}(\mathrm{bpy})_{3}\right]^{2+}$, annihilation ECL intensities of the four $\mathrm{Ru}(\mathrm{II})$ complexes ranged between $7 \%$ and $95 \%$. Moreover, the imidazoylidene-NHC analogues exhibited a bathochromic shift (8-13 nm) due to destabilisation of the metal-based highest occupied molecular orbital (HOMO) with only minor destabilisation of the bpy ligand-based lowest unoccupied molecular orbital (LUMO). In contrast, the complexes containing a benzimidazolylidene-NHC were hypsochromically shifted (7-12 nm) due to HOMO stabilisation (with little or no effect on the LUMO), in which case it was concluded that $\pi$-back bonding mitigated the typically strong $\sigma$-donation of NHCs. Park and co-workers $^{26}$ reported a wider spread of emissions (from greenish-yellow to red) in the annihilation and co-reactant ECL of three $\mathrm{Ru}(\mathrm{II})$ complexes bearing tridentate NHC ligands (a)

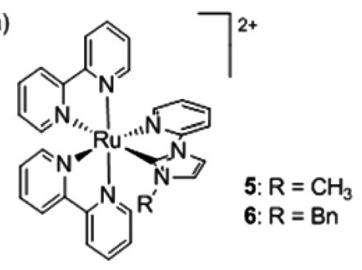

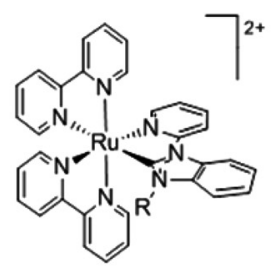

8: $\mathrm{R}=\mathrm{Bn}$

(b)
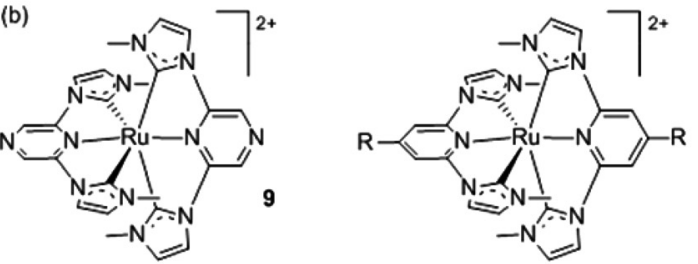

10: $\mathrm{R}=\mathrm{H}$ 11: $R=2-P y$

(c)

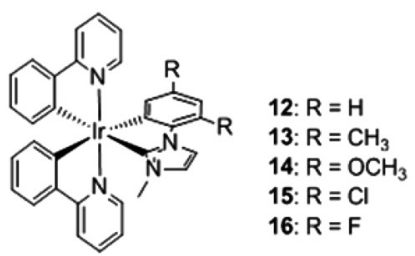

(d)
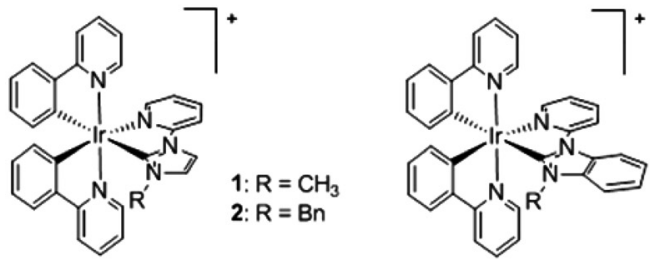

3: $\mathrm{R}=\mathrm{CH}_{3}$

Scheme 1 (a-c) Representative Ru(II) and Ir(III) complexes incorporating NHC ligands that have been previously examined for their ECL activity. ${ }^{26,32,33}$ (d) The Ir(III) complexes examined in this study.
(9-11, Scheme 1b), but their ECL intensities were not compared to $\left[\mathrm{Ru}(\mathrm{bpy})_{3}\right]^{2+}$.

We also recently reported the ECL properties of five $\operatorname{Ir}(\mathrm{III})$ complexes that each contained two cyclometalated 2-(phenyl)pyridine (ppy) ligands and a 2,4-disubstituted phenyl-imidazoylidene NHC ligand (12-16, Scheme 1c). ${ }^{33}$ The addition of electron withdrawing halogen substituents on the phenyl ring of the NHC ligand alone shifted the emission maxima from $532 \mathrm{~nm}$ to $524 \mathrm{~nm}(\mathrm{Cl})$ or $490 \mathrm{~nm}$ (F), which was predominantly attributed to their stabilising inductive effects on the substantially metal-based HOMO, compared to the ppy-based LUMO. In contrast, resonance electron-donation of the methoxy substituents was not significant due to its meta position. Reasonably intense annihilation ECL was observed from each of the Ir(III) complexes, but only the difluoro derivative produced significant ECL via the co-reactant pathway. ${ }^{33}$ These findings, in conjunction with other ECL investigations, ${ }^{47}$ led us to propose a plot of oxidation potential versus emission colour as a convenient guide to the energy sufficiency of novel metal complexes for co-reactant ECL. Herein, we report the first examination of ECL with $\operatorname{Ir}(\mathrm{III})$ complexes containing a pyridyl-imidazoylidene- or pyridyl-benzimidazolylidene-NHC ligand (1-4, Scheme 1d). This not only provides new insight into the potential application of NHC ligands in ECL systems, but also aptly illustrates the additional factors apart from energetics that must be considered, when using an oxidation potential versus emission wavelength plot, as a predictor of coreactant ECL ability.

\section{Results and discussion}

\section{Synthesis}

The desired azolium salts I·I, II·Br, III.I and IV·Br (Scheme 2), were prepared by heating either 1-(2-pyridyl)imidazole or 1-(2pyridyl)benzimidazole with the appropriate alkyl halide (methyl iodide or benzyl bromide) in $\mathrm{CH}_{3} \mathrm{CN}$ as has been described previously. ${ }^{32}$

Formation of the $\left[\operatorname{Ir}(p p y)_{2}\left(\mathrm{C}^{\wedge} \mathrm{N}\right)\right]^{+}$complexes (where $\mathrm{C}^{\wedge} \mathrm{N}$ is a bidentate NHC ligand derived from the azolium salts $\mathbf{I} \cdot \mathbf{I}$, II·Br, III·I and IV·Br) was carried out using Ag(I) transmetallation utilising $\mathrm{Ag}_{2} \mathrm{O}$ and the dinuclear $\mathrm{Ir}(\mathrm{III})$ precursor compound, $\left[\operatorname{Ir}(\mathrm{ppy})_{2} \mathrm{Cl}\right]_{2}$, in a 1:1 mixture of $\mathrm{CH}_{2} \mathrm{Cl}_{2}$ and $\mathrm{CH}_{3} \mathrm{OH}$ (Scheme 3). ${ }^{18}$ Initial attempts to synthesise the $\operatorname{Ir}(\mathrm{III})$ complexes
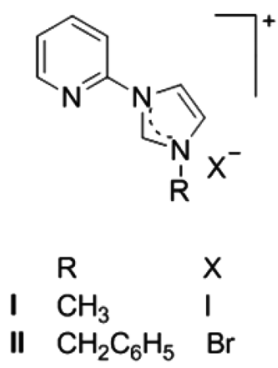
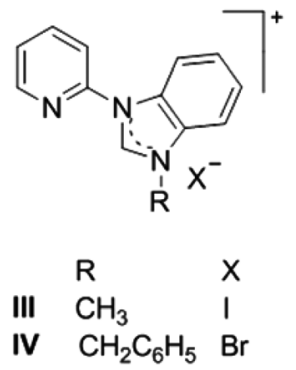

Scheme 2 Structures of the azolium salts I.I, II.Br, III.I and IV.Br. 

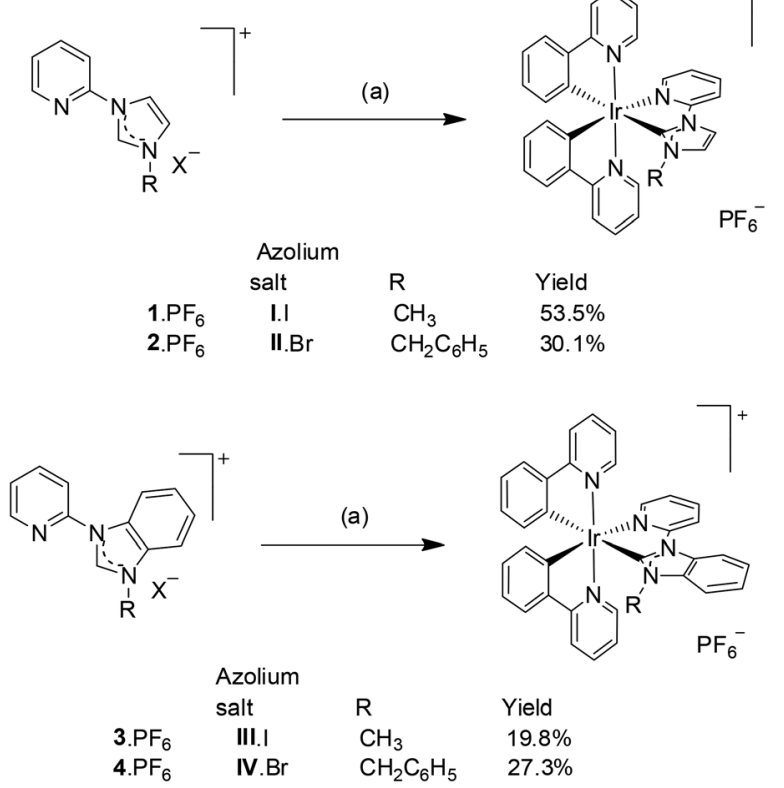

Scheme 3 Synthesis of iridium(III) complexes 1. $\left(\mathrm{PF}_{6}\right)-4 \cdot\left(\mathrm{PF}_{6}\right)$. Reagents and conditions: (a) 1. azolium salt, $\mathrm{Ag}_{2} \mathrm{O}$ in a mixture of $\mathrm{CH}_{2} \mathrm{Cl}_{2}$ and $\mathrm{CH}_{3} \mathrm{OH}(1: 1), 80^{\circ} \mathrm{C}, 4 \mathrm{~h}$; 2. [Ir $(\mathrm{ppy})_{2} \mathrm{Cl}_{2}, 17 \mathrm{~h}$; 3. aq. $\mathrm{KPF}_{6}$.

utilising the hexafluorophosphate salts of the azolium cations, resulted is very low yields (3-8\%). In subsequent attempts the halide salts of the azolium cations (I·I, II $\cdot \mathbf{B r}$, III $\cdot \mathbf{I}$ and $\mathbf{I X} \cdot \mathbf{B r}$ ) were used and increased yield of the recrystallised $\operatorname{Ir}(\mathrm{III})$ complexes were obtained (20-54\%).

\section{Characterisation}

The structure of the azolium salts and the $\left[\operatorname{Ir}(\mathrm{ppy})_{2}\left(\mathrm{C}^{\wedge} \mathrm{N}\right)\right]^{+}$ complexes were confirmed by ${ }^{1} \mathrm{H}$ and ${ }^{13} \mathrm{C}$ NMR spectroscopy and in the case of the $1 \cdot \mathrm{PF}_{6}, \mathbf{3} \cdot \mathrm{PF}_{6}$ and $\mathbf{4} \cdot \mathrm{PF}_{6}$, by X-ray crystallography. The predicted number of signals were obtained in the ${ }^{1} \mathrm{H}$ and ${ }^{13} \mathrm{C}$ spectra for the synthesised $\left[\operatorname{Ir}(\mathrm{ppy})_{2}\left(\mathrm{C}^{\wedge} \mathrm{N}\right)\right]^{+}$complexes, consistent with the low symmetry structures $\left(C_{1}\right.$ point group). Fig. S1 and $\mathrm{S} 2 \uparrow$ show representative ${ }^{1} \mathrm{H}$ and ${ }^{13} \mathrm{C}$ NMR spectra for compounds $2 \cdot \mathrm{PF}_{6}$ and $3 \cdot \mathrm{PF}_{6}$ (ESI $\dagger$ ). As expected, upon coordination of the NHC unit, the signal for the azolium salt procarbenic proton was lost from the ${ }^{1} \mathrm{H}$ NMR spectra and a characteristic down-field chemical shift was observed for the carbenic (NHC) carbon atom, occurring at 177.5, 178.7, 187.4 and $188.8 \mathrm{ppm}$ for the ${ }^{13} \mathrm{C}$ spectra of complexes $1 \cdot \mathrm{PF}_{6}-\mathbf{4} \cdot \mathrm{PF}_{6}$, respectively. For complexes $3 \cdot \mathrm{PF}_{6}$ and $4 \cdot \mathrm{PF}_{6}$, where the NHC is substituted with a benzyl group, the protons of the methylene linker are non-equivalent and a characteristic AX pattern was observed. These methylene protons are enantiotopic and non-equivalent as a result of the chirality associated with the octahedral tris(bidentate) $\operatorname{Ir}(\mathrm{III})$ complexes $(\Delta$ and $\Lambda$ ).

Single crystals of the $\operatorname{Ir}(\mathrm{III})$ complexes $1 \cdot \mathrm{PF}_{6}, 3 \cdot \mathrm{PF}_{6}$ and $4 \cdot \mathrm{PF}_{6}$ were grown by slow evaporation of methanol solutions of each compound. The structure of $\mathbf{1} \cdot \mathrm{PF}_{6}$ has been reported previously ${ }^{18}$ and is included here for the purpose of comparison. The X-ray crystal structures of the $\operatorname{Ir}(\mathrm{III})$ cations $\mathbf{1}^{+}, \mathbf{3}^{+}$and $\mathbf{4}^{+}$

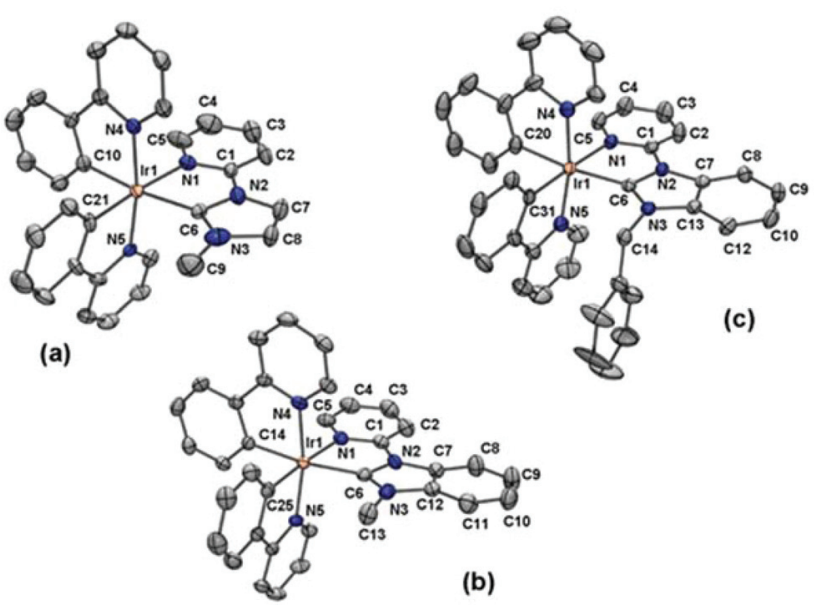

Fig. 1 ORTEP ${ }^{51}$ representations of the $\mathrm{X}$-ray crystal structures of the Ir(III) cations: (a) $1^{+}$, (b) $3^{+}$and (c) $4^{+}$. The $\mathrm{PF}_{6}{ }^{-}$anions have been omitted for clarity. Thermal ellipsoids are shown at $40 \%$ probability. Labelled according to cif files. Selected bond distances given in Table 1.

Table 1 Selected bond distances for compounds $1^{+}, 3^{+}$and $4^{+}$from X-ray crystallography ${ }^{a}$

\begin{tabular}{llll}
\hline Bond distance & $\mathbf{1}^{+}$ & $3^{+}$ & $\mathbf{4}^{+}$ \\
\hline Ir-N1 & $2.140(5)$ & $2.170(4)$ & $2.147(2)$ \\
Ir-N2 & $2.050(4)$ & $2.058(4)$ & $2.050(2)$ \\
Ir-N3 & $2.044(5)$ & $2.049(3)$ & $2.035(2)$ \\
Ir-C1 & $2.075(5)$ & $2.061(4)$ & $2.046(2)$ \\
Ir-C2 & $2.007(5)$ & $2.015(4)$ & $2.009(2)$ \\
Ir-C3 & $2.051(5)$ & $2.046(4)$ & $2.053(2)$
\end{tabular}

${ }^{a}$ For the purpose of comparison, a common labelling is used here that differs slightly from Fig. 1 (cif file labelling).

are shown in Fig. 1, with selected bond distances collated in Table 1 and crystal refinement data summarised in Table 2 . The molecular structures all display slightly distorted octahedral coordination geometries ( $C_{1}$ point group) around the Ir(III) centres with two cyclometalating ppy ligands and the bidentate NHC-pyridine unit. In each case the pyridine groups of the cyclometallated ppy ligands are trans to each other, while the ppy phenyl rings are cis to each other.

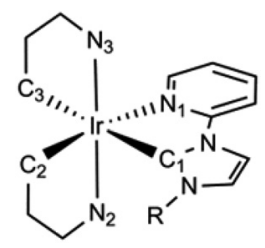

The Ir- $\mathrm{C}_{\mathrm{NHC}}$ (Ir-C1 in Table 1) bond distance for the imidazolylidene containing complex $\left(\mathbf{1}^{+}\right)$is $2.075(5) \AA$, which is slightly longer than $2.064 \AA$ from the crystal structure of Zhang et al. for the same compound, ${ }^{18}$ and consistent with previously reported iridium imidazolylidene complexes. For an analogous complex of $\mathbf{1}^{+}$with two cyclometalating 2-(2,4-difluorophenyl)pyridine ligands, the $\operatorname{Ir}-\mathrm{C}_{\mathrm{NHC}}$ bond distance is $2.060(5) \AA{ }^{20}$ 
Table 2 Electrochemical and ECL properties of 1.PF $-4 \cdot \mathrm{PF}_{6}$, in comparison with $\left[\mathrm{Ru}(\mathrm{bpy})_{3}\right]\left(\mathrm{PF}_{6}\right)_{2}$ and related Ru(II) and $\operatorname{Ir}(\mathrm{II})$ complexes containing $\mathrm{NHC}$ ligands $26,32,33$

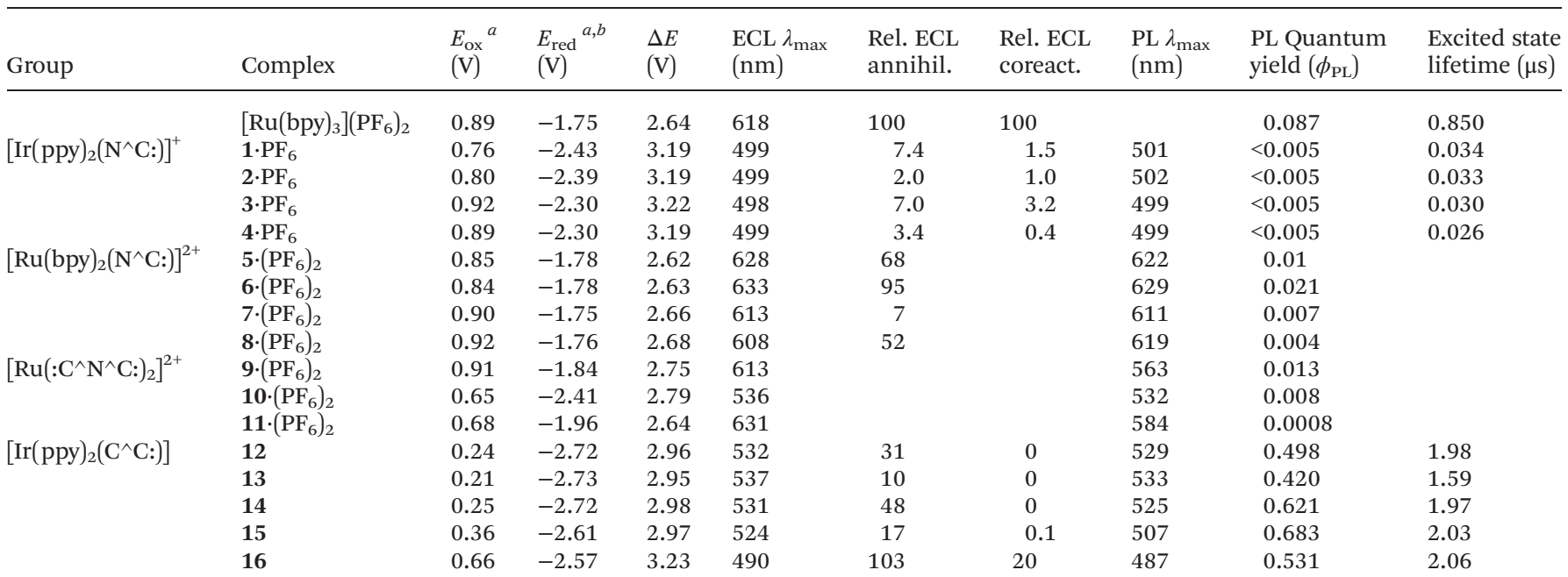

${ }^{a} E^{\circ}$ or $E^{\frac{1}{2}}$ values for reversible or irreversible peaks, as stated in original papers. In the case of $\mathbf{1} \cdot \mathrm{PF}_{6}-\mathbf{4} \cdot \mathrm{PF}_{6}$, the values are $E^{\frac{1}{2}}$ taken at a scan rate of $0.1 \mathrm{~V} \mathrm{~s}^{-1}$ (see Fig. 3a). ${ }^{b}$ Only first reduction potential listed.

Zhang et al. ${ }^{48}$ reported an Ir- $\mathrm{C}_{\mathrm{NHC}}$ distance of 2.068(6) $\AA$ for a compound similar in structure to $2^{+}$(differs in having a $\mathrm{N}_{\mathrm{NHC}}-\mathrm{Ph}$ rather than $\mathrm{N}_{\mathrm{NHC}^{-}}-\mathrm{CH}_{2} \mathrm{Ph}$ substituent). Slightly shorter Ir- $\mathrm{C}_{\mathrm{NHC}}$ bond distances have been reported for a homoleptic Ir(III) complex of a cyclometalated imidazolylidene-based NHC ligand (1.91 and $1.97 \AA)^{49}$ and a naphthyridine-functionalized $\operatorname{Ir}(\mathrm{III})-\mathrm{NHC}(1.93(1) \AA ̊.){ }^{50}$

For the benzimidazolylidene-containing complexes the Ir- $\mathrm{C}_{\mathrm{NHC}}$ bond distances are 2.061(4) and 2.046(2) $\AA$ for $3^{+}$and $4^{+}$, respectively, which are relatively consistent and also similar to that determined for the imidazolylidene containing complex $\mathbf{1}^{+}$. Previously reported benzimidazolylidene-containing structures include a series of complexes closely related to $2^{+}$with a variety of cyclometalating 2-(phenyl)pyridine ligands, with $\mathrm{Ir}-\mathrm{C}_{\mathrm{NHC}}$ bond distances in the range of 2.060(5) to 2.076(4) $\AA^{19,20}$ For a homoleptic Ir(III) complex of a cyclometalated benzimidazolylidene-based $\mathrm{NHC}$ ligand $\left(f a c-\operatorname{Ir}(\mathrm{pmb})_{3}\right)$, the average Ir- $\mathrm{C}_{\mathrm{NHC}}$ bond distance was 2.026(7) $\AA^{52}{ }^{52}$

A marked trans influence from the carbene is apparent, with a significant elongation of the Ir- $\mathrm{C}_{\mathrm{PPY}}$ bond trans to the $\mathrm{C}_{\mathrm{NHC}}$ donor (2.051(5), 2.046(4) and 2.053(2) $\AA$ for $\mathbf{1}^{+}, \mathbf{3}^{+}$and $\mathbf{4}^{+}$, respectively) when compared to the other $\mathrm{Ir}-\mathrm{C}_{\mathrm{PPY}}$ bond distances of 2.007(5), 2.015(4) and 2.009(2) $\AA$ for $\mathbf{1}^{+}, \mathbf{3}^{+}$and $\mathbf{4}^{+}$, respectively. The trans effect is observed in similar NHCcontaining iridium(III) complexes. ${ }^{18-20,48,53}$

\section{Absorption spectroscopy}

The absorption spectra of the complexes $\mathbf{1} \cdot \mathrm{PF}_{6}-\mathbf{4} \cdot \mathrm{PF}_{6}$ were recorded in acetonitrile solutions at room temperature (Fig. 2a and Table S7†). The absorption bands at high energy $(<340 \mathrm{~nm})$ can be assigned to $\pi \rightarrow \pi^{*}$ transitions involving the co-ordinated heterocyclic ligands, whereas the weaker bands $(>340 \mathrm{~nm})$ can be assigned to spin-allowed metal-to-ligand charge-transfer $\left({ }^{1} \mathrm{MLCT}\right)$ transitions in addition to spin-
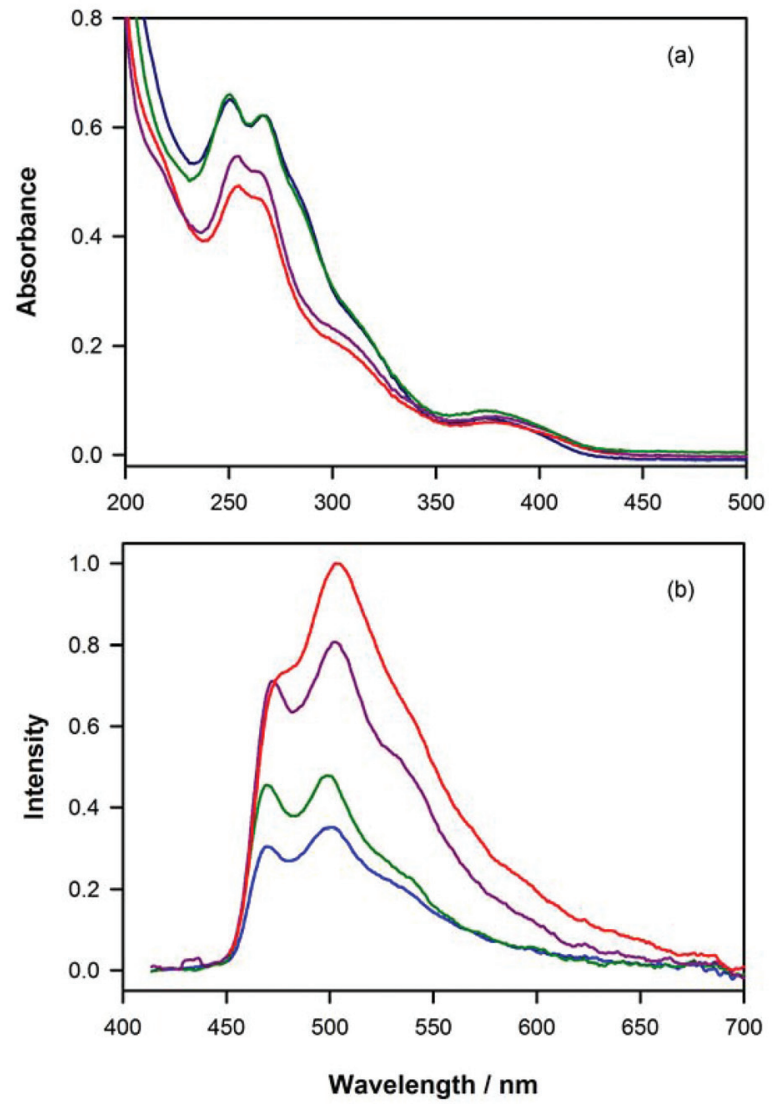

Fig. 2 (a) Absorption spectra and (b) photoluminescence emission spectra $\left(\lambda_{\text {ex }}=400 \mathrm{~nm}\right)$ of complexes 1.PF (purple line), 2. $\mathrm{PF}_{6}$ (red), $3 \cdot \mathrm{PF}_{6}$ (green) and $4 \cdot \mathrm{PF}_{6}$ (blue) at $10 \mu \mathrm{M}$ and $1 \mu \mathrm{M}$, respectively, in acetonitrile at room temperature. 
forbidden ${ }^{3}$ MLCT transitions promoted by the strong spinorbit coupling of the heavy-atom metal centre. ${ }^{54,55}$

\section{Photoluminescence spectroscopy}

Complexes 1. $\mathrm{PF}_{6}-\mathbf{4} \cdot \mathrm{PF}_{6}$ each showed blue-green phosphorescent emission at room temperature in acetonitrile under deaerated conditions. Despite the differences in the structure of the NHC ligand, the photoluminescence spectra of $1 \cdot \mathrm{PF}_{6}-\mathbf{4} \cdot \mathrm{PF}_{6}$ (Fig. 2b) were quite similar, exhibiting maximum intensity at 499-502 $\mathrm{nm}$, with a prominent shoulder or peak at $\sim 470 \mathrm{~nm}$ and a broad shoulder at $\sim 540 \mathrm{~nm}$. These emissions have much more structure than those of the $\left[\mathrm{Ru}(\mathrm{bpy})_{2}\left(\mathrm{~N}^{\wedge} \mathrm{C}:\right)\right]^{2+}$ complexes containing pyridyl-imidazoylidene (Fig. 1a: $5 \cdot\left(\mathrm{PF}_{6}\right)_{2}$ and 6. $\left.\left(\mathrm{PF}_{6}\right)_{2}\right)$ or pyridyl-benzimidazolylidene-NHCs $\left(7 \cdot\left(\mathrm{PF}_{6}\right)_{2}\right.$ and 8. $\left.\left(\mathrm{PF}_{6}\right)_{2}\right),{ }^{32}$ or the $\left[\operatorname{Ir}(\mathrm{ppy})_{2}\left(\mathrm{C}^{\wedge} \mathrm{C}:\right)\right]$ complexes containing phenyl-imidazoylidene-NHCs (Fig. 1c: 12-16), ${ }^{33}$ which is indicative of weak MLCT character and a pronounced LC $\pi \rightarrow \pi^{*}$ contribution. ${ }^{18,55}$ The photoluminescence quantum yields of the $\left[\operatorname{Ir}(\mathrm{ppy})_{2}\left(\mathrm{~N}^{\wedge} \mathrm{C}:\right)\right]^{+}$complexes $\mathbf{1} \cdot \mathrm{PF}_{6}-\mathbf{4} \cdot \mathrm{PF}_{6}$ in acetonitrile were all less than $1 \%$, which is poor compared to the $\left[\operatorname{Ir}(\mathrm{ppy})_{2}\left(\mathrm{C}^{\wedge} \mathrm{C}:\right)\right]$ complexes 12-16 $(42-68 \%),{ }^{33}$ but close to those of the $\left[\mathrm{Ru}(\mathrm{bpy})_{2}\left(\mathrm{~N}^{\wedge} \mathrm{C}:\right)\right]^{2+}$ complexes $\mathbf{5} \cdot\left(\mathrm{PF}_{6}\right)_{2}-\mathbf{8} \cdot\left(\mathrm{PF}_{6}\right)_{2}$ $(0.4-2 \%) .^{32}$ Similarly, Zhang et al. ${ }^{18}$ reported a low quantum yield of $0.5 \%$ for complex $1 \cdot \mathrm{PF}_{6}$ in degassed acetonitrile at room temperature, which was attributed to significant nonradiative energy-transfer to solvent. Baranoff and co-workers ${ }^{20}$ reported a quantum yield of $0.6 \%$ for a complex that differed from $3 \cdot \mathrm{PF}_{6}$ by a methyl group on the pyridyl ring of the pyridylbenzimidazolylidene NHC ligand. The difference in quantum yields between the $\mathrm{C}^{\wedge} \mathrm{C}$ coordinated and $\mathrm{N}^{\wedge} \mathrm{C}$ coordinated iridium NHC complexes is striking. For example, complexes $\mathbf{1 2}$ and $\mathbf{1}$ differ by only one atom, yet their efficiencies of photoluminescence are 0.498 and 0.006 respectively. This may be explained by differing abilities of the two types of NHC ligand to de-stabilise thermally accessible metal centred $\left({ }^{3} \mathrm{MC}\right)$ non-emissive states. The short lifetimes of complexes 1-4 compared with those of 12-16 tend to support this conclusion. A similar theory was suggested by Thompson and coworkers ${ }^{56}$ for tris-cyclometalated $\left(\mathrm{N}^{\wedge} \mathrm{C}\right)$ iridium complexes and by Baranoff and co-workers ${ }^{20}$ on the basis of temperaturedependent excited-state lifetime measurements on complexes with similar NHC ligands to ours.

\section{Electrochemistry}

The redox properties of $\mathbf{1} \cdot \mathrm{PF}_{6}-\mathbf{4} \cdot \mathrm{PF}_{6}$ were studied using cyclic voltammetry and the results are compared with selected data from previous papers ${ }^{26,32,33}$ in Table 2. All complexes displayed reduction peaks between -1.30 and $-1.43 \mathrm{~V} v s$. Fc, which were chemically irreversible (i.e. no return peak) at all scan rates tested, (Fig. 3a). Similarly, at $0.1 \mathrm{~V} \mathrm{~s}^{-1}$, irreversible peaks due to oxidation of the complexes were seen between 0.76 and $0.92 \mathrm{~V} v s$. Fc. However, these oxidation processes became more chemically reversible at slightly elevated scan rates. For example, when complexes $1 \cdot \mathrm{PF}_{6}$ and $2 \cdot \mathrm{PF}_{6}$ were scanned at rates $\geq 0.1 \mathrm{~V} \mathrm{~s}^{-1}$ and complexes $3 \cdot \mathrm{PF}_{6}$ and $4 \cdot \mathrm{PF}_{6}$ at rates $\geq 0.5 \mathrm{~V}$ $\mathrm{s}^{-1}$, they exhibited responses that were semi-reversible

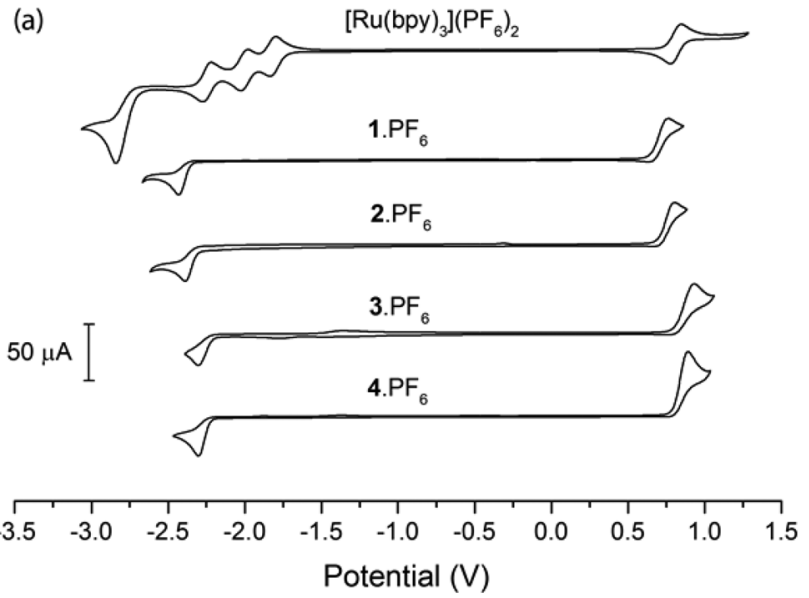

(b)

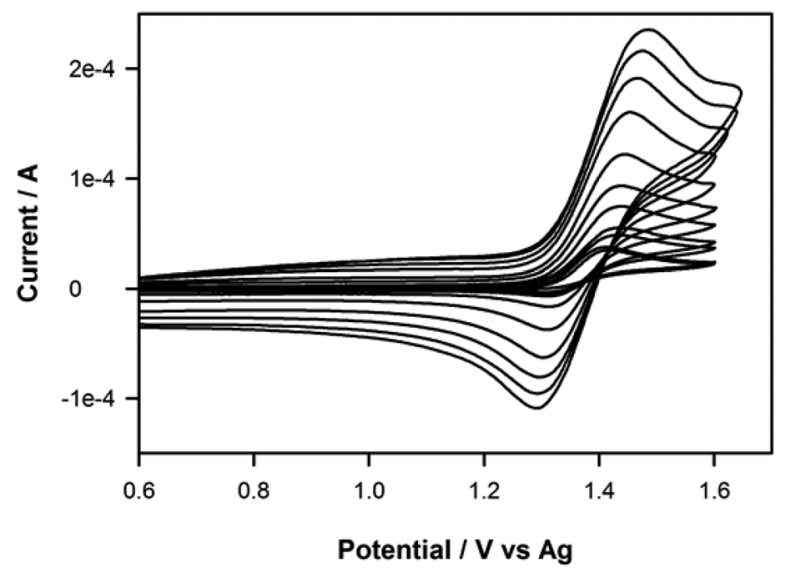

Fig. 3 (a) Cyclic voltammetric responses (scan rate $=0.1 \mathrm{~V} \mathrm{~s}^{-1}$ ) for complexes 1. $\mathrm{PF}_{6}-4 \cdot \mathrm{PF}_{6}$ and $\left[\mathrm{Ru}(\mathrm{bpy})_{3}\right]\left(\mathrm{PF}_{6}\right)_{2}(1 \mathrm{mM})$ dissolved in acetonitrile containing $0.1 \mathrm{M}\left[\mathrm{Bu}_{4} \mathrm{~N}\right] \mathrm{PF}_{6}$. (b) Change in the oxidative cyclic voltammetric response from irreversible to reversible for complex 4. $\mathrm{PF}_{6}$ as the scan rates were increased from 0.08 to $25.00 \mathrm{~V} \mathrm{~s}^{-1}$.

chemically $\left(i_{\mathrm{p}, \mathrm{ox}}>i_{\mathrm{p}, \text { red }}\right)$ and became fully reversible $\left(i_{\mathrm{p}, \mathrm{ox}} /\right.$ $\left.i_{\mathrm{p}, \text { red }}=1\right)$ at scan rates of greater than or equal to $1,5,3$ and $5 \mathrm{~V} \mathrm{~s}^{-1}$ for complexes $1 \cdot \mathrm{PF}_{6}, 2 \cdot \mathrm{PF}_{6}, 3 \cdot \mathrm{PF}_{6}$ and $4 \cdot \mathrm{PF}_{6}$, respectively (Fig. 3b).

The oxidation potentials, which in this case can be formally assigned to the $\mathrm{Ir}^{3+/ 4+}$ redox couple (although the HOMO is delocalised over the phenyl ring of the ppy ligands), were similar in magnitude to those of the $\mathrm{Ru}^{2+/ 3+}$ couple in $\left[\mathrm{Ru}(\mathrm{bpy})_{3}\right]^{2+}$ and the previously reported $\left[\mathrm{Ru}(\mathrm{bpy})_{2}\left(\mathrm{~N}^{\wedge} \mathrm{C}:\right)\right]^{2+}$ complexes 5. $\left(\mathrm{PF}_{6}\right)_{2}-\mathbf{8} \cdot\left(\mathrm{PF}_{6}\right)_{2}$, but much more positive than the $\mathrm{Ir}^{3+/ 4+}$ couple of the $\left[\operatorname{Ir}(\mathrm{ppy})_{2}\left(\mathrm{C}^{\wedge} \mathrm{C}:\right)\right]$ complexes 12-16. This is due to the much greater electron donation of the orthometalating ring of the phenyl-imidazoylidene or phenyl-benzimidazolylidene NHC ligands than the nitrogen lone pair of their pyridyl analogues.

As observed for the $\left[\mathrm{Ru}(\mathrm{bpy})_{2}\left(\mathrm{~N}^{\wedge} \mathrm{C}:\right)\right]^{2+}$ complexes, ${ }^{32}$ the benzimidazolylidene-NHC ligand of complexes $3 \cdot \mathrm{PF}_{6}$ and $4 \cdot \mathrm{PF}_{6}$ resulted in more positive oxidation potentials and larger HOMO-LUMO gaps than the analogous imidazolylidene-NHC 
ligand of $1 \cdot \mathrm{PF}_{6}$ and $2 \cdot \mathrm{PF}_{6}$, which can be attributed to stabilisation of the HOMO by benzimidazolylidene $\pi$-backbonding. In contrast to the oxidation potentials, the (primarily ligandbased) first reduction potentials of complexes $1 \cdot \mathrm{PF}_{6}-\mathbf{4} \cdot \mathrm{PF}_{6}$ were more akin to those of the $\left[\operatorname{Ir}(\mathrm{ppy})_{2}\left(\mathrm{C}^{\wedge} \mathrm{C}:\right)\right]$ series than the $\left[\mathrm{Ru}(\mathrm{bpy})_{3}\right]^{2+}$ and $\left[\mathrm{Ru}(\mathrm{bpy})_{2}\left(\mathrm{~N}^{\wedge} \mathrm{C}:\right)\right]^{2+}$ complexes, because the bipyridine ligands are much more easily reduced than the phenylpyridine or NHC ligands.

\section{Electrogenerated chemiluminescence}

Under oxidative potential with TPA as a co-reactant, the relative ECL intensities of the $\left[\operatorname{Ir}(\mathrm{ppy})_{2}\left(\mathrm{~N}^{\wedge} \mathrm{C}:\right)\right]^{+}$complexes $\mathbf{1} \cdot \mathrm{PF}_{6}-\mathbf{4} \cdot \mathrm{PF}_{6}$ were $0.4-3.2 \%$ that of $\left[\mathrm{Ru}(\mathrm{bpy})_{3}{ }^{2+}\right]$. These are higher than that of $\left[\operatorname{Ir}(\mathrm{ppy})_{2}\left(\mathrm{C}^{\wedge} \mathrm{C}:\right)\right]$ complexes 12-15 $(\leq 0.1 \%$; Table 2$)$, but much lower than that of the difluoro derivative $16(20 \%) .^{33}$ In contrast, under annihilation conditions, the ECL intensities of complexes $\mathbf{1} \cdot \mathrm{PF}_{6}-\mathbf{4} \cdot \mathrm{PF}_{6}(\leq 7.4 \%)$ were poorer than those of either the $\left[\operatorname{Ir}(\text { ppy })_{2}\left(\mathrm{C}^{\wedge} \mathrm{C}:\right)\right](10-103 \%)$ or $\left[\mathrm{Ru}(\mathrm{bpy})_{2}\left(\mathrm{~N}^{\wedge} \mathrm{C}:\right)\right]^{2+}$ $(7-95 \%)$ series. These findings can be effectively rationalised by considering the dominant factors that determine the relative intensities in each mode of ECL. In the case of co-reactant ECL using relatively high concentrations of TPA, the major reaction pathway can be summarised as follows, ${ }^{57}$ where $\mathrm{M}$ is the metal-complex electrochemiluminophore, and $\mathrm{P}$ is other products.

$$
\begin{gathered}
\mathrm{M}-\mathrm{e}^{-} \rightarrow \mathrm{M}^{+} \\
\mathrm{TPA}^{-} \mathrm{e}^{-} \rightarrow \mathrm{TPA}^{\cdot+} \\
\mathrm{TPA}^{\cdot+} \rightarrow \mathrm{TPA}^{\cdot}+\mathrm{H}^{+} \\
\mathrm{M}^{+}+\mathrm{TPA}^{\cdot} \rightarrow \mathrm{M}^{*}+\mathrm{P} \\
\mathrm{M}^{*} \rightarrow \mathrm{M}+h \nu
\end{gathered}
$$

Intense co-reactant ECL with TPA could be expected from complexes that: (i) have an appropriately high oxidation potential, so that there is sufficient excess energy in reaction (4) to generate the product in an electronically excited state; (ii) are sufficiently stable in their oxidised form; and (iii) have a high luminescence quantum yield. With respect to factor (i), we recently introduced a graph of oxidation potential versus emission wavelength indicating the 'wall of energy sufficiency' for co-reactant ECL with TPA, ${ }^{33}$ which can be derived from the following relationship for the free energy of reaction (4):

$$
\Delta G=E_{\mathrm{red}}-E_{\mathrm{ox}}+E_{\mathrm{ES}}
$$

In the case of co-reactant ECL with TPA, the $E_{\text {red }}$ is $E\left(\right.$ TPA $\left.^{*}\right)$, which has been previously reported as $-2.1 \mathrm{~V}(\nu s . \mathrm{Fc}) .{ }^{57}$ The energy of the excited state, $E_{\mathrm{ES}}$, is best taken from the maximum emission wavelength at low temperature, but may be estimated using room temperature data to a first approximation. As illustrated by Fig. 4, there is clearly sufficient free energy for the generation of the excited states in the $\left[\operatorname{Ir}(\mathrm{ppy})_{2}\left(\mathrm{~N}^{\wedge} \mathrm{C}:\right)\right]^{+} \quad\left(\mathbf{1} \cdot \mathrm{PF}_{6}-\mathbf{4} \cdot \mathrm{PF}_{6}\right), \quad\left[\mathrm{Ru}(\mathrm{bpy})_{2}\left(\mathrm{~N}^{\wedge} \mathrm{C}:\right)\right]^{2+}\left(\mathbf{5} \cdot\left(\mathrm{PF}_{6}\right)_{2}-\right.$ 8. $\left.\left(\mathrm{PF}_{6}\right)_{2}\right)$, and $\left[\mathrm{Ru}\left(: \mathrm{C}^{\wedge} \mathrm{N}^{\wedge} \mathrm{C}:\right)_{2}\right]^{2+}\left(\mathbf{9} \cdot\left(\mathrm{PF}_{6}\right)_{2}-\mathbf{1 1} \cdot\left(\mathrm{PF}_{6}\right)_{2}\right)$ complexes, but members of the previously investigated $\left[\operatorname{Ir}(\mathrm{ppy})_{2}\left(\mathrm{C}^{\wedge} \mathrm{C}:\right)\right]$

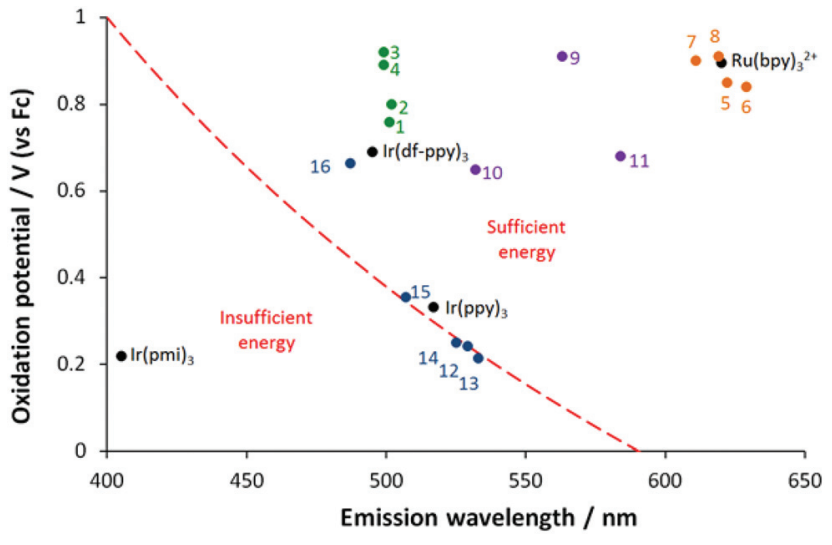

Fig. 4 'Wall of energy sufficiency' for co-reactant ECL with TPA. The dashed line represents the critical oxidation potential required for $\mathrm{ECL}$ for a luminophore with a given emission colour. Solid circles show the position of $\left[\operatorname{Ir}(\mathrm{ppy})_{2}\left(\mathrm{~N}^{\wedge} \mathrm{C}:\right)\right]^{+}$complexes $1 \cdot \mathrm{PF}_{6}-4 \cdot \mathrm{PF}_{6}$ (green circles), [Ru$\left.(\text { bpy })_{2}\left(\mathrm{~N}^{\wedge} \mathrm{C}:\right)\right]^{2+}$ complexes ${ }^{32} 5 \cdot\left(\mathrm{PF}_{6}\right)_{2}-8 \cdot\left(\mathrm{PF}_{6}\right)_{2}$ (orange), $\left[\mathrm{Ru}\left(: \mathrm{C}^{\wedge} \mathrm{N}^{\wedge} \mathrm{C}:\right)_{2}\right]^{2+}$ complexes $^{26}$ 9.(PF $)_{2}-11 \cdot\left(\mathrm{PF}_{6}\right)_{2}$ (purple), and $\left[\operatorname{lr}(\mathrm{ppy})_{2}\left(\mathrm{C}^{\wedge} \mathrm{C}:\right)\right] \mathrm{com}-$ plexes $^{33} 12-16$ (blue).

series fall on both sides of the 'wall'. Complexes 12-14, which showed no co-reactant ECL with TPA (Table 2) were found to be energy insufficient. Complex 15, which exhibited weak coreactant ECL intensity, was adjacent to the wall, whereas complex 16, which gave the most intense co-reactant ECL, was positioned well within the energy sufficient zone. Complexes $1 \cdot \mathrm{PF}_{6}-\mathbf{4} \cdot \mathrm{PF}_{6}$ were positioned even further away from the wall (near the $\left[\mathrm{Ru}(\mathrm{bpy})_{3}\right]^{2+}$ reference complex), but their corresponding co-reactant ECL intensities were much poorer than those of either complex 16 or $\left[\mathrm{Ru}(\mathrm{bpy})_{3}\right]^{2+}$. Although complexes $\mathbf{1} \cdot \mathrm{PF}_{6}-\mathbf{4} \cdot \mathrm{PF}_{6}$ have oxidation potentials that would certainly provide adequate free energy upon reaction with TPA ${ }^{\circ}$ to generate the excited state, their co-reactant ECL is limited by factors (ii) and (iii). Due to the apparent instability of their dications, the voltammetric responses for the oxidation of complexes $\mathbf{1} \cdot \mathrm{PF}_{6}-\mathbf{4} \cdot \mathrm{PF}_{6}$ were only reversible at relatively fast scan rates (Fig. 3b), whereas the oxidation of $\left[\mathrm{Ru}(\mathrm{bpy})_{3}\right]^{2+}$ (Fig. 3a) and complex $\mathbf{1 6}$ are fully chemically reversible at relatively low scan rates. ${ }^{33}$ Moreover, the photoluminescence quantum yields of $\mathbf{1} \cdot \mathrm{PF}_{6}-\mathbf{4} \cdot \mathrm{PF}_{6}(<1 \%)$ were poor compared to $\left[\mathrm{Ru}(\mathrm{bpy})_{3}\right]^{2+}(9 \%)$ and the $\left[\operatorname{Ir}(\mathrm{ppy})_{2}\left(\mathrm{C}^{\wedge} \mathrm{C}:\right)\right]$ complexes $\mathbf{1 2 - 1 6}$ $(42-68 \%)$.

In the case of annihilation ECL, the reductant utilised to generate the electronically excited state is derived from electrolysis of the metal complex:

$$
\begin{gathered}
\mathrm{M}+\mathrm{e}^{-} \rightarrow \mathrm{M}^{-} \\
\mathrm{M}^{+}+\mathrm{M}^{-} \rightarrow \mathrm{M}^{*}+\mathrm{M}
\end{gathered}
$$

Entering the $E_{\mathrm{ox}}, E_{\mathrm{red}}$ and $E_{\mathrm{ES}}$ data from Table 2 into eqn (6) shows that the annihilation reaction (8) of each complex has sufficient free energy to generate the product in an electronically excited state. Here, however, the reversibility of both the oxidation and reduction potentials must be considered, in 
addition to the luminescence quantum yield. Complex 16 for example, exhibited an annihilation ECL intensity that was $103 \%$ that of $\left[\mathrm{Ru}(\mathrm{bpy})_{3}\right]^{2+}$, which can be attributed at least in part to its greater quantum yield, as both complexes have highly reversible oxidation and reduction potentials. ${ }^{33}$ Although complexes 12-15 also have high quantum yields, their oxidation potentials were less reversible, which can account for their moderate annihilation ECL intensities (10-48\%). The $\left[\mathrm{Ru}(\mathrm{bpy})_{2}\left(\mathrm{~N}^{\wedge} \mathrm{C}:\right)\right]^{2+}$ complexes $\mathbf{5} \cdot\left(\mathrm{PF}_{6}\right)_{2}-\mathbf{8} \cdot\left(\mathrm{PF}_{6}\right)_{2}$ exhibit reversible $\mathrm{Ru}^{2+/ 3+}$-oxidation and bipyridine-ligandreduction potentials, but they have poorer luminescence quantum yields than $\left[\mathrm{Ru}(\mathrm{bpy})_{3}\right]^{2+}$, somewhat accounting for their reduced but still significant annihilation ECL intensities (7-95\%). In contrast, weak annihilation ECL was observed from complexes $1 \cdot \mathrm{PF}_{6}-\mathbf{4} \cdot \mathrm{PF}_{6}$, due to a combination of their low quantum yields and their instability in both the oxidised and reduced form as revealed by the limited reversibility of their reduction and oxidation processes.

\section{Theoretical studies}

The mPW1PW91/SDD,6-31+G(d) gas-phase optimized geometries (Table 2) of the iridium complexes 1-4 (omitting $\mathrm{PF}_{6}{ }^{-}$ counter-ions) are in good agreement with the X-ray structures (Table 1), with differences between calculated and experimental Ir-N and Ir-C bond distances for $\mathbf{1}^{+}, \mathbf{3}^{+}$, and $\mathbf{4}^{+}$all less than $0.07 \AA$ (mean absolute deviation of $0.02 \AA$ ).

The mPW1PW91 calculated bond distances and Wiberg bond indices (WBI) for $\mathrm{Ir}-\mathrm{N}$ and $\mathrm{Ir}-\mathrm{C}$ reflect the difference between the imidazolylidene $\left(\mathbf{1}^{+}\right.$and $\left.\mathbf{2}^{+}\right)$and benzimidazolylidene $\left(3^{+}\right.$and $\left.\mathbf{4}^{+}\right)$containing complexes (see Table 3 ). In $\mathbf{1}^{+}$and $2^{+}$, the Ir- $\mathrm{C}_{\mathrm{NHC}}$ bond distance is slightly longer than those for $3^{+}$and $4^{+}$, and this small difference is reflected in the WBI values (indicative of bond order). For the other coordination bonds ( $\mathrm{Ir}-\mathrm{N}$ and $\mathrm{Ir}-\mathrm{C}_{\mathrm{NHC}}$ ), there is no appreciable difference in bond distances and WBI values between the imidazolylidene $\left(\mathbf{1}^{+}\right.$and $\left.\mathbf{2}^{+}\right)$and benzimidazolylidene $\left(3^{+}\right.$and $\left.4^{+}\right)$containing complexes. The well-known trans influence ${ }^{58-61}$ from the NHC group is replicated in the theoretical results, with calculated Ir- $\mathrm{C}_{\mathrm{PPY}}($ trans $)$ bond distances (2.048-2.051 $\AA$ ) significantly longer than the other $\operatorname{Ir} 1-\mathrm{C}_{\mathrm{PPY}}($ cis $)$ bond distances (2.004-2.008 $\AA$ ) (Table 3).

Table 3 Selected mPW1PW91/SDD,6-31+G(d) calculated bond distances (Å) for complexes $1^{2+}-4^{2+}$. Wiberg bond indices (WBI) from mPW1PW91/SDD, TZVP single point calculations inclusive of acetonitrile solvent

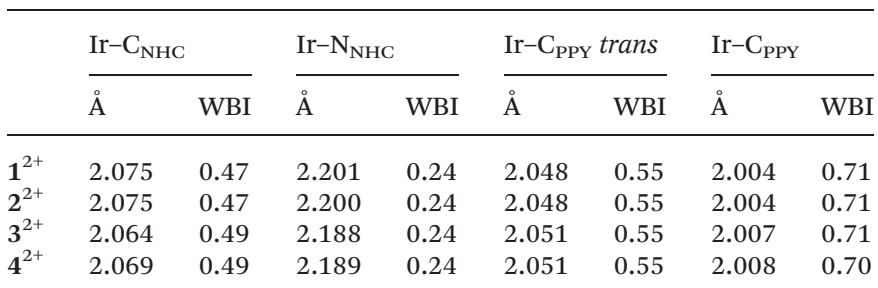

Analysis of the frontier MOs (Fig. 5, S4-7†) indicates that for all compounds, the singlet HOMO is comprised of contributions from the iridium $\mathrm{d}$ and phenyl $\pi$ orbitals, distributed across both ppy ligands. The singlet LUMO is comprised of a majority contribution from the auxiliary NHC ligand, with a smaller contribution from the ppy ligands. In the imidazolylidene complexes $\left(\mathbf{1}^{+}-\mathbf{2}^{+}\right)$the contribution is $\sim 30 \%$, whereas in the benzimidazolylidene complexes $\left(3^{+}-\mathbf{4}^{+}\right)$it is $\sim 15 \%$. Similar subtle differences are noted in the LUMO+1 between $\mathbf{1}^{+}-2^{+}$ $(\sim 60 \% \mathrm{NHC})$ and $3^{+}-\mathbf{4}^{+}(\sim 80 \% \mathrm{NHC})$, and also in the HOMO -1 for $\mathbf{1}^{+}-2^{+}\left(\sim 15 \%\right.$ Ir) and $3^{+}-\mathbf{4}^{+}$(7\% Ir). For other relevant frontier orbitals in $\mathbf{1}^{+}-\mathbf{4}^{+}$, there is no discernible difference between contributions from the different fragments.

For all of $\mathbf{1}^{+}-\mathbf{4}^{+}$, the singlet-state HOMO and LUMO do overlap (i.e. they are not entirely orthogonal), which suggests that the HOMO and LUMO energies cannot be easily 'tuned' by substitution of the ligands. Moreover, the triplet state density (Fig. S8†) does not share the same spatial extent as the singlet HOMO and LUMO.

It is instructive to compare the characteristics of the MOs of the Ir compounds considered here and the analogous Ru compounds (bpy in place of ppy) considered previously. ${ }^{32}$ With $\mathrm{Ru}$, the HOMO, HOMO-1 and HOMO-2 are all largely metal based, whereas in the Ir compounds the HOMO-1 is mostly associated with the ppy ligand (the HOMO and HOMO-2 are metal based). For the unoccupied MOs, the density plots are qualitatively similar however there is a different energy ordering. With $\mathrm{Ru}$, the LUMO and LUMO+1 are associated with the bpy ligands and the LUMO+2 resides on the auxiliary NHC ligand, whereas in the Ir compounds the LUMO and LUMO+2 are associated with the ppy ligand and the LUMO+1 resides on the NHC ligand. That is, with Ir the NHC $\pi^{*}$ MO is stabilised relative to the $\mathrm{Ru}$ compounds and hence may be expected to have a greater impact on photophysical and electrochemical properties.

Calculated energies of valence orbitals of complexes $\mathbf{1}^{+} \mathbf{4}^{+}$ are included in Table 4 . The energy of the HOMOs of $3^{+}$and $4^{+}$ are slightly lower than those for $\mathbf{1}^{+}$and $2^{+}$. It is suggested that the benzimidazolylidene exerts a greater stabilising influence on the metal-based HOMO than does the imidazolylidene. The blue-shifted MLCT bands from the absorption spectra of $3^{+}$ and $\mathbf{4}^{+}$are consistent with the benzimidazolylidene exerting a stabilising influence on the metal-based HOMO. There is no discernible LUMO energy difference. The HOMO-LUMO energy gap of $\mathbf{1}^{+}-\mathbf{2}^{+}$is less than that of $\mathbf{3}^{+}-\mathbf{4}^{+}$, which is consistently reproduced by MPW1PW91, B3LYP and M06 density functionals. The larger HOMO-LUMO gap for $3^{+}$and $\mathbf{4}^{+}$(consistent with the analysis of luminescence spectra) arises from the lower HOMO energies of $\mathbf{3}^{+}$and $\mathbf{4}^{+}$.

Calculation of electronic excitations with TD-DFT (mPW1PW91) supports the above discussion of the spectroscopic and electrochemical results (Fig. S9, Table S5†), with transitions in the visible region best described as MLCT, and transitions in the UV region of the spectrum dominated by intra-ligand charge transfer (ILCT) and ligand-centred (LC) transitions. 

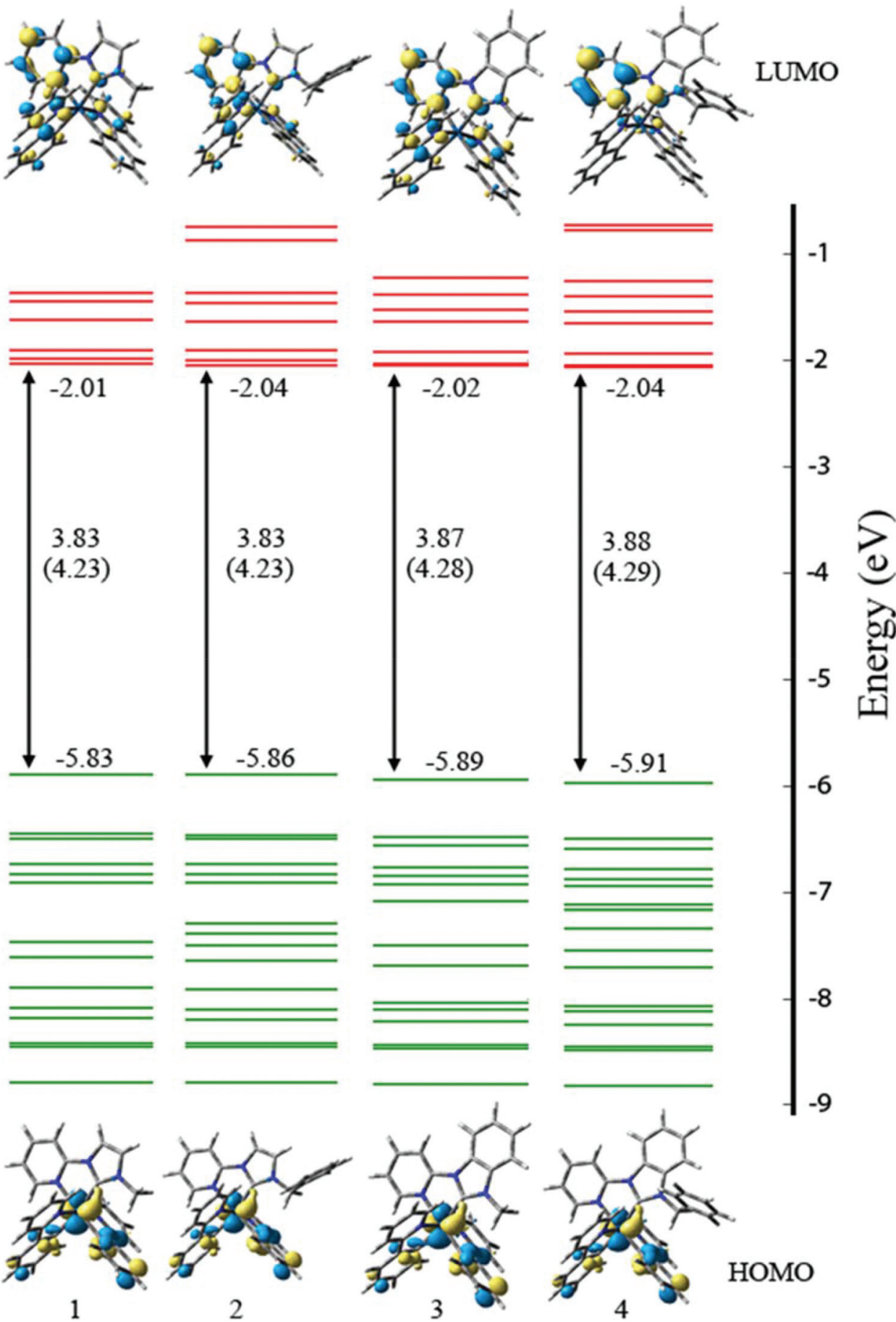

Fig. 5 B3LYP/SDD,tzvp//mPW1PW91/SDD,6-31+G(d) calculated molecular orbital energy diagram including HOMO-LUMO gaps (mPW1PW91/SDD, tzvp result in parentheses), and surface plots of the HOMO and LUMO for 1-4. Acetonitrile solvent correction included with single-pint SCRF. Units of eV.

\section{Conclusions}

A family of four heteroleptic iridium(III) complexes of the form $\left[\operatorname{Ir}(\operatorname{ppy})_{2}\left(\mathrm{C}^{\wedge} \mathrm{N}\right)\right] \mathrm{PF}_{6}$ (where $\mathrm{C}^{\wedge} \mathrm{N}$ is a pyridyl-imidazolylidene or pyridyl-benzimidazolylidene NHC ligand) were synthesized in a relatively straight forward manner using a $\mathrm{Ag}(\mathrm{I})$ transmetalla- tion protocol. A combined theoretical and experimental investigation into the spectroscopic and electrochemical properties of the series was performed with a view to gaining a better understanding into reasons behind the varying efficiency of the photoluminescence and electrochemically generated luminescence observed for such complexes. To this end, the 
Table 4 DFT calculated HOMO, LUMO and HOMO-LUMO energies $(\mathrm{eV})^{a}$

\begin{tabular}{llllllll}
\hline & \multicolumn{2}{l}{ mPW1PW91 } & & & \multicolumn{2}{l}{ B3LYP } \\
& HOMO & LUMO & $\Delta E$ & & HOMO & LUMO & $\Delta E$ \\
\hline $\mathbf{1}^{2+}$ & -6.12 & -1.89 & 4.23 & & -5.83 & -2.01 & 3.82 \\
$\mathbf{2}^{2+}$ & -6.13 & -1.90 & 4.23 & & -5.86 & -2.04 & 3.82 \\
$\mathbf{3}^{2+}$ & -6.18 & -1.89 & 4.28 & & -5.89 & -2.02 & 3.87 \\
$\mathbf{4}^{2+}$ & -6.20 & -1.91 & 4.29 & & -5.91 & -2.04 & 3.87
\end{tabular}

${ }^{a}$ SDD,TZVP basis set and effective core potential with acetonitrile PCM SCRF.

properties of the four complexes were compared with those of similar NHC complexes of iridium and ruthenium recently reported by ourselves and others in the literature.

The photoluminescence quantum yields for $\mathbf{1} \cdot \mathrm{PF}_{6}-\mathbf{4} \cdot \mathrm{PF}_{6}$ were all found to be below $1 \%$, contrasting with the strongly luminescent complexes 12-16. The lesser abilities of the $\mathrm{N}^{\wedge} \mathrm{C}$ coordinated ligands to de-stabilise thermally accessible nonemissive states, compared to the $\mathrm{C}^{\wedge} \mathrm{C}$ variety, is the most likely reason for this. ${ }^{20}$ Varying the structure and substituents on the NHC ligand in compounds $\mathbf{1} \cdot \mathrm{PF}_{6}-\mathbf{4} \cdot \mathrm{PF}_{6}$ had a negligible effect on the colour of the emission with $\lambda_{\max }$ being virtually identical in each case. This is explained by the fact that neither of the frontier orbitals is located on or in close proximity to the NHC ring of the auxiliary ligand, as determined from DFT calculations, therefore electron donating or withdrawing effects on these orbitals tend to be weak and to be directed with approximately equal influence toward the HOMO and LUMO. In the case of the ruthenium analogues 5-8, where moderate differences in $\lambda_{\max }$ were observed, the HOMO was substantially metal based, allowing this orbital to be directly influenced by structural differences in the NHC moiety. The electrochemical results bear out this analysis; for example, although the oxidation potentials of $1 \cdot \mathrm{PF}_{6}-\mathbf{4} \cdot \mathrm{PF}_{6}$ differ by up to $160 \mathrm{mV}$, the gap between oxidation and reduction processes (the electrochemical HOMO-LUMO gap) is almost invariant at about $3.20 \pm 0.01 \mathrm{~V}$. The electrochemical responses for $1 \cdot \mathrm{PF}_{6}$ $4 \cdot \mathrm{PF}_{6}$ are characterised by chemical irreversibility of both the oxidative and reductive processes, pointing to instability in both the oxidised and reduced forms of the complexes, though the oxidation couple become reversible at faster scan rates. The electrochemiluminescence intensities (both annihilation and co-reactant modes) observed for compounds $\mathbf{1} \cdot \mathrm{PF}_{6}-\mathbf{4} \cdot \mathrm{PF}_{6}$ were quite weak. This is due a combination of low photoluminescence quantum yield and instability in the oxidised and reduced forms of the complex. A plot of oxidation potential versus emission wavelength was constructed to rationalise the influence of energetics on ECL intensity for these and the previously investigated NHC complexes (5-16). This plot demonstrates that favourable energetics is necessary, but is not the only condition required for intense ECL. For example, 1. $\mathrm{PF}_{6}-\mathbf{4} \cdot \mathrm{PF}_{6}$ have favourable energetics for ECL but their efficiency is confounded by unfavourable kinetic and photophysical factors. On the other hand, compounds 12-15 exhibit high photoluminescence quantum yields and reversible electrochemistry, but unfavourable energetics. In the cases of 16 and $\left[\mathrm{Ru}(\mathrm{bpy})_{3}\right]^{2+}$, however, all constraints are satisfied and intense ECL is observed.

\section{Experimental section}

\section{General}

All reagents were purchased from Sigma-Aldrich and were of analytical grade or higher and were used without further purification unless otherwise stated. Dry $\mathrm{CH}_{3} \mathrm{CN}$ and THF were distilled from $\mathrm{CaH}_{2}$ and sodium benzophenone ketyl under nitrogen, respectively. Ligands I-IV were prepared using previously published procedures. ${ }^{32}$ NMR spectra were recorded using Bruker ARX-300 (300.14 MHz for ${ }^{1} \mathrm{H}, 75.48 \mathrm{MHz}$ for ${ }^{13} \mathrm{C}$ ) and referenced to solvent resonances. Microanalyses were performed by the Microanalytical Laboratory at the ANU Research School of Chemistry, Canberra, Australia. All compounds were prepared in air unless otherwise specified.

\section{Absorption and photoluminescence spectroscopy}

UV-visible absorption spectra were collected using a Cary 300 Bio UV-Vis spectrophotometer (Varian Australia, Mulgrave, Vic., Australia) with $1 \mathrm{~cm}$ path length quartz cells. Photoluminescence spectra were collected with a Cary Eclipse Spectrofluorimeter (Varian Australia), using a $1 \mathrm{~cm}$ quartz cuvette (5 nm bandpass, $1 \mathrm{~nm}$ data interval, PMT voltage: $800 \mathrm{~V})$. Emission spectra correction factors were established using an Optronic Laboratories spectral irradiance standard (model OL $245 \mathrm{M}$ ) with constant current source (model OL 65A). UV-visible and photoluminescence spectra were recorded at $10 \mu \mathrm{M}$ and $1 \mu \mathrm{M}$ concentrations respectively in acetonitrile. Lifetimes were measured with a Nanolog (HORIBA Jobin Yvon IBH) spectrometer using the time correlated single photon counting (TCSPC) option and correlated by a time-to-amplitude converter (TAC) in forward TAC mode. $10 \mu \mathrm{M}$ solutions were prepared in an air-tight four-sided quartz cuvette in a oxygen-free glovebox using acetonitrile which had been purged using the freeze-pump-thaw method. The complexes were excited using a Nanoled $340(344 \mathrm{~nm})$ laser pulsed at $100 \mathrm{kHz}$ repetition rate. The emitted photons were detected by a thermoelectrically cooled TBX picosecond single-photon detector with the emission band width set to $10 \mathrm{~nm}$. Signals were collected using a FluoroHub counter and the decay curves were fitted to a single exponential using DAS6 software (HORIBA Jobin Yvon IBH). Weighted residuals averaging around zero and a $\chi^{2}<1.2$ were used to judge a good fit.

\section{Electrochemistry and electrogenerated chemiluminescence}

Experiments were performed using Autolab PGSTAT 101 (for cyclic voltammograms) and Autolab PGSTA12 (for chronoamperometry and cyclic voltammograms with ECL detection) potentiostats (Metrohm Autolab B.V., Netherlands). The electrochemical cell consisted of a cylindrical glass cell with a quartz window base and Teflon cover with spill tray. The cell 
was encased in a custom-built light-tight faraday cage. A conventional three electrode configuration, consisting of a glassy carbon $3 \mathrm{~mm}$ diameter working electrode, shrouded in Teflon (CH Instruments, Austin, TX, USA), reference electrode and gold wire counter electrode. Potentials were referenced to the ferrocene/ferrocenium couple measured in situ $(1 \mathrm{~mm})$ in each case. ECL spectra were obtained using an Ocean Optics CCD, model QE65pro, interfaced with our electrochemical cell using an optic fibre $(1.0 \mathrm{~m}, 1.0 \mathrm{~mm}$ core diameter $)$, collimating lens, and custom cell holder, and the acquisition was triggered using a HR 4000 Break-Out box in conjunction with the potentiostat. The complexes were prepared in freshly distilled acetonitrile at a concentration of $1 \mathrm{~mm}$ for voltammetric and ECL measurements, with $0.1 \mathrm{~m}$ tetrabutylammonium hexafluorophosphate $\left(\mathrm{TBAPF}_{6}\right)$ as the supporting electrolyte, with a coreactant (TPA) concentration of $10 \mathrm{~mm}$ for ECL experiments. Prior to each experiment, the working electrode was polished using $0.3 \mu \mathrm{m}$ and then $0.05 \mu \mathrm{m}$ alumina with water on a felt pad, sonicated in MilliQ water $(1 \mathrm{~min})$, rinsed in freshly distilled acetonitrile and dried with a stream of $\mathrm{N}_{2}$. The working electrode was then positioned at an appropriate distance ( $\sim 2 \mathrm{~mm}$ ) from the bottom of the cell for detection of the ECL signal, and the solution was purged with grade 5 argon for 15 min prior to measurement. ECL spectra were recorded using a $45 \mathrm{~s}$ integration time, and single $40 \mathrm{~s}$ chronoamperometry pulse at $1.4 \mathrm{~V}$. Spectra were integrated to determine the relative ECL intensities and compared with the ECL spectrum of the standard $\left(\left[\mathrm{Ru}(\mathrm{bpy})_{3}\right]^{2+}\right)$ measured under identical conditions.

\section{X-ray crystallography}

Single crystals of the iridium complexes $1 \cdot\left(\mathrm{PF}_{6}\right), \mathbf{3} \cdot\left(\mathrm{PF}_{6}\right)$ and $\mathbf{4} \cdot\left(\mathrm{PF}_{6}\right)$ suitable for $\mathrm{X}$-ray diffraction studies were grown by slow evaporation of methanol solutions of each compound. Crystallographic data for all structures determined are given in Table 2. Crystals were mounted on a glass fibre in paratone oil and cooled rapidly to $173 \mathrm{~K}$ in a stream of cold $\mathrm{N}_{2}$ using an Oxford low-temperature device. Diffraction data were measured using an Oxford Gemini dual-wavelength X-ray diffractometer mounted with molybdenum (Mo) and copper (Cu) X-ray sources (graphite-monochromated $\mathrm{Mo}-\mathrm{K} \alpha$ and $\mathrm{Cu}-\mathrm{K} \alpha$ radiation, $\lambda=0.71073 \AA$ and $\lambda=1.54184 \AA$, respectively). Data were reduced and corrected for absorption using the CrysAlis Pro program. ${ }^{61}$ The SHELXL2013-2 program $^{62}$ was used to solve the structures with Direct Methods, with refinement by the Full-Matrix Least-Squares refinement techniques on $F^{2}$. The non-hydrogen atoms were refined anisotropically and hydrogen atoms were placed geometrically and refined using the riding model. Coordinates and anisotropic thermal parameters of all non-hydrogen atoms were refined. All calculations were carried out using the program Olex ${ }^{2}{ }^{63}$ Images were generated by using ORTEP-3. ${ }^{51}$ Further XRD details are provided in the ESI. $\uparrow$ CCDC 1031786-1031788 contains the supplementary crystallographic data for this paper.

\section{Theoretical calculations}

Density functional theory (DFT) calculations were carried out within the Gaussian 09 suite of programs. ${ }^{64}$ Ground state geometries were optimised in the absence of solvent with B3LYP $^{65-67}$ and mPW1PW91 ${ }^{68,69}$ functionals in conjunction with the $6-31+G(d)$ basis set ${ }^{70-72}$ for non-metal atoms and the SDD basis set and MWB core potential for iridium. ${ }^{73,74}$ Only mPW1PW91 results are presented since it has been shown previously that this functional yields reliable results. ${ }^{32,75,76}$ Singlepoint energy calculations were carried out at the optimised geometries using the SDD basis and core potential (MWB $)^{73,74}$ for Ir and the TZVP basis $\operatorname{set}^{77}$ for all other atoms. The polarisable continuum model (PCM) ${ }^{78}$ self-consistent reaction field (SCRF) was used to model solvent effects at the gas-phase optimised geometries with a solvent of acetonitrile, consistent with the experimental system. Frontier MO energies were calculated using DFT MOs. Excitation energies to singlet and triplet excited states were investigated with TD-DFT ${ }^{79}$ with 40 states calculated. An SCF convergence criteria of $10^{-8}$ a.u. was employed throughout. Molecular orbital analysis was carried out with the AOMix program ${ }^{80}$ and NBO 5.9. ${ }^{81}$

\section{Synthesis}

1.PF : $_{6}$ A mixture of $\mathbf{I} \cdot \mathbf{I}(0.2 \mathrm{~g}, 0.66 \mathrm{mmol})$ and $\mathrm{Ag}_{2} \mathrm{O}(0.23 \mathrm{~g}$, $0.94 \mathrm{mmol})$ in $1: 1 \mathrm{CH}_{2} \mathrm{Cl}_{2}-\mathrm{CH}_{3} \mathrm{OH}(50 \mathrm{~mL})$ was heated in the dark at $80{ }^{\circ} \mathrm{C}$ for $4 \mathrm{~h}$ under $\mathrm{N}_{2} \cdot\left[\operatorname{Ir}(\mathrm{ppy})_{2} \mathrm{Cl}\right]_{2} \quad(0.37 \mathrm{~g}$, $0.35 \mathrm{mmol}$ ) was added and this temperature was maintained for $17 \mathrm{~h}$. The hot reaction mixture was filtered through celite and water $(30 \mathrm{~mL})$ and $\mathrm{KPF}_{6}(0.6 \mathrm{~g}, 3.2 \mathrm{mmol})$ were added to the filtrate. After $1 \mathrm{~h}$ the bright green precipitate was collected and recrystallised from methanol giving the product as a bright green solid (Yield: $0.3 \mathrm{~g}, 53.5 \%) .{ }^{1} \mathrm{H}$ NMR $\left(d_{6}\right.$-DMSO): $\delta(\mathrm{ppm})=8.49(\mathrm{~d}, J=2.1 \mathrm{~Hz}, 1 \mathrm{H}), 8.32(\mathrm{~d}, J=8.1 \mathrm{~Hz}, 1 \mathrm{H})$, 8.17-8.24 (m, 3H), $7.96(\mathrm{~d}, J=5.4 \mathrm{~Hz}, 1 \mathrm{H}), 7.84-7.92(\mathrm{~m}, 4 \mathrm{H})$, $7.57(\mathrm{t}, J=5.4 \mathrm{~Hz}, 2 \mathrm{H}), 7.50(\mathrm{~d}, J=2.1 \mathrm{~Hz}, 1 \mathrm{H}), 7.40(\mathrm{t}, J=6.3$, $6.6 \mathrm{~Hz}, 1 \mathrm{H}), 7.12(\mathrm{t}, J=6.9,8.4 \mathrm{~Hz}, 2 \mathrm{H}), 7.00(\mathrm{t}, J=7.2,6.9 \mathrm{~Hz}$, $1 \mathrm{H}), 6.91(\mathrm{dd}, J=6.9,5.4 \mathrm{~Hz}, 2 \mathrm{H}), 6.77(\mathrm{t}, J=7.2,6.9 \mathrm{~Hz}, 1 \mathrm{H})$, $6.24(\mathrm{~d}, J=7.2 \mathrm{~Hz}, 1 \mathrm{H}), 6.09$ (d, $J=6.9 \mathrm{~Hz}, 1 \mathrm{H}), 3.07$ (s, 3H, $\left.\mathrm{CH}_{3}\right) .{ }^{13} \mathrm{C} \mathrm{NMR}\left(d_{6}\right.$-DMSO $): \delta(\mathrm{ppm})=177.5,167.9,166.6,164.0$, 153.6 , 153.2, 149.2, 149.1, 149.0, 144.6, 142.8, 141.8, 138.5, $137.7,130.5,130.3,129.7,125.5,125.0,124.6,124.3,123.6$, 122.8, 121.1, 120.2, 119.9, 117.9, 112.9, 36.3. Found: C, 46.43; $\mathrm{H}, 3.16 ; \mathrm{N}, 8.74 \% . \mathrm{C}_{31} \mathrm{H}_{25} \mathrm{~N}_{5} \mathrm{PF}_{6}$ Ir requires $\mathrm{C}, 46.27 ; \mathrm{H}, 3.13$; $\mathrm{N}, 8.70 \%$.

2. $\mathrm{PF}_{6}$ : This compound was prepared as described for $\mathbf{1} \cdot\left(\mathrm{PF}_{6}\right)$ from II. $\mathrm{Br}(0.2 \mathrm{~g}, 0.63 \mathrm{mmol}), \mathrm{Ag}_{2} \mathrm{O}(0.22 \mathrm{~g}, 0.95 \mathrm{mmol})$ and $\left[\operatorname{Ir}(\text { ppy })_{2} \mathrm{Cl}\right]_{2} \quad(0.34 \mathrm{~g}, 0.32 \mathrm{mmol})$ in $1: 1 \quad \mathrm{CH}_{2} \mathrm{Cl}_{2}-\mathrm{CH}_{3} \mathrm{OH}$ $(50 \mathrm{~mL})$. The product was obtained as a bright yellow solid after recrystallisation from a mixture of methanol and water. (Yield: $0.17 \mathrm{~g}, 30.1 \%) .{ }^{1} \mathrm{H}$ NMR $\left(d_{6}\right.$-DMSO): $\delta(\mathrm{ppm})=8.60(\mathrm{~s}$, $1 \mathrm{H}), 8.35$ (d, $J=8.4 \mathrm{~Hz}, 1 \mathrm{H}), 8.16-8.24(\mathrm{~m}, 2 \mathrm{H}), 7.99$ (d, $J=$ $5.7 \mathrm{~Hz}, 1 \mathrm{H}), 7.81-7.93(\mathrm{~m}, 4 \mathrm{H}), 7.62(\mathrm{~d}, J=5.7 \mathrm{~Hz}, 1 \mathrm{H})$, $7.49-7.57(\mathrm{~m}, 3 \mathrm{H}), 7.40(\mathrm{t}, J=6.6,6.3 \mathrm{~Hz}, 1 \mathrm{H}), 7.11(\mathrm{t}, J=7.2$, $6.3 \mathrm{~Hz}, 3 \mathrm{H}), 6.97(\mathrm{t}, J=7.5,7.2 \mathrm{~Hz}, 3 \mathrm{H}), 6.89(\mathrm{t}, J=6.6,7.2 \mathrm{~Hz}$, $1 \mathrm{H}), 6.70-6.76(\mathrm{~m}, 2 \mathrm{H}), 6.31(\mathrm{~d}, J=7.5 \mathrm{~Hz}, 2 \mathrm{H}), 6.19(\mathrm{~d}, J=$ 
$6.9 \mathrm{~Hz}, 1 \mathrm{H}), 6.05(\mathrm{~d}, J=7.2 \mathrm{~Hz}, 1 \mathrm{H}), 4.80(\mathrm{dd}, J=15.3 \mathrm{~Hz}, 2 \mathrm{H}$, $\left.-\mathrm{CH}_{2}\right) \cdot{ }^{13} \mathrm{C}$ NMR $\left(d_{6}\right.$-DMSO): $\delta(\mathrm{ppm})=178.7,167.9,166.5$, $163.7,153.5,153.2,149.1,148.6,144.5,143.0$, 141.8, 138.6, $137.5,136.4,130.5,130.4,130.2,129.6,128.2,127.4,125.8$, 125.0, 124.9, 124.4, 123.4, 122.8, 120.9, 120.3, 119.9, 119.0, 113.1, 52.1. Found: C, 48.39; H, 3.27; N, 8.09\%. $\mathrm{C}_{35} \mathrm{H}_{27} \mathrm{~N}_{5} \mathrm{PF}_{6} \mathrm{Ir} \cdot \mathrm{CH}_{3} \mathrm{OH}$ requires $\mathrm{C}, 48.76 ; \mathrm{H}, 3.52 ; \mathrm{N}, 7.90 \%$.

3. $\mathrm{PF}_{6}$ : This compound was prepared as described for $\mathbf{1} \cdot\left(\mathrm{PF}_{6}\right)$ from III.I $(0.2 \mathrm{~g}, 0.59 \mathrm{mmol}), \mathrm{Ag}_{2} \mathrm{O}(0.2 \mathrm{~g}, 0.89 \mathrm{mmol})$ and [Ir(ppy) $\left.)_{2} \mathrm{Cl}\right]_{2}(0.32 \mathrm{~g}, 0.29 \mathrm{mmol})$ in $1: 1 \mathrm{CH}_{2} \mathrm{Cl}_{2}-\mathrm{CH}_{3} \mathrm{OH}(50 \mathrm{~mL})$. The product was obtained as a bright green solid after recrystallisation from hot methanol (Yield: $0.09 \mathrm{~g}, 19.8 \%) .{ }^{1} \mathrm{H}$ NMR $\left(d_{6}\right.$-DMSO $): \delta(\mathrm{ppm})=8.71(\mathrm{~d}, J=8.7 \mathrm{~Hz}, 1 \mathrm{H}), 8.48-8.52(\mathrm{~m}$, $1 \mathrm{H}), 8.18-8.25(\mathrm{~m}, 4 \mathrm{H}), 7.87-7.90(\mathrm{~m}, 4 \mathrm{H}), 7.67-7.70(\mathrm{~m}, 2 \mathrm{H})$, $7.63(\mathrm{~d}, J=5.1 \mathrm{~Hz}, 1 \mathrm{H}), 7.51-7.56(\mathrm{~m}, 2 \mathrm{H}), 7.43(\mathrm{t}, J=6 \mathrm{~Hz}$, $1 \mathrm{H}), 6.99-7.10(\mathrm{~m}, 3 \mathrm{H}), 6.92(\mathrm{dd}, J=5.7,4.2 \mathrm{~Hz}, 2 \mathrm{H}), 6.84(\mathrm{t}$, $J=6 \mathrm{~Hz}, 1 \mathrm{H}), 6.28(\mathrm{~d}, J=6.6 \mathrm{~Hz}, 1 \mathrm{H}), 6.06(\mathrm{~d}, J=6.3 \mathrm{~Hz}, 1 \mathrm{H})$, $3.31\left(\mathrm{~s}, 3 \mathrm{H}, \mathrm{CH}_{3}\right) .{ }^{13} \mathrm{C} \mathrm{NMR}\left(d_{6}\right.$-DMSO): $\delta(\mathrm{ppm})=187.4,167.5$, $166.5,164.5,154.3,153.8,149.6,149.2,144.4,142.9,142.0$, $138.7,137.9,136.4,131.2,130.6,130.5,130.3,129.9,125.2(2)$, $125.1,124.9,124.7,123.9,123.6,123.0,121.4,120.3(2), 114.0$, 112.9, 112.5, 33.4. Found: C, 50.45; H, 3.32; N, 7.95\%. $\mathrm{C}_{37} \mathrm{H}_{29} \mathrm{~N}_{5} \mathrm{PF}_{6}$ Ir requires C, 50.54; H, 3.52; N, 8.09\%.

4. $\cdot \mathrm{PF}_{6}$ : This compound was prepared as described for $\mathbf{1} \cdot\left(\mathrm{PF}_{6}\right)$ from IV·Br $(0.2 \mathrm{~g}, 0.55 \mathrm{mmol}), \mathrm{Ag}_{2} \mathrm{O}(0.19 \mathrm{~g}, 0.82 \mathrm{mmol})$ and $\left[\operatorname{Ir}(\text { ppy })_{2} \mathrm{Cl}\right]_{2} \quad(0.3 \mathrm{~g}, \quad 0.27 \mathrm{mmol})$ in $1: 1 \quad \mathrm{CH}_{2} \mathrm{Cl}_{2}-\mathrm{CH}_{3} \mathrm{OH}$ $(50 \mathrm{~mL})$. The product was obtained as a bright yellow solid after recrystallisation from acetonitrile (Yield: $0.14 \mathrm{~g}, 27.3 \%$ ). ${ }^{1} \mathrm{H}$ NMR $\left(d_{6}\right.$-DMSO): $\delta(\mathrm{ppm})=8.76(\mathrm{~d}, J=8.4 \mathrm{~Hz}, 1 \mathrm{H}), 8.57(\mathrm{~d}$, $J=8.4 \mathrm{~Hz}, 1 \mathrm{H}), 8.17-8.25(\mathrm{~m}, 3 \mathrm{H}), 7.82-7.90(\mathrm{~m}, 4 \mathrm{H}), 7.72(\mathrm{t}$, $J=6,6.3 \mathrm{~Hz}, 2 \mathrm{H}), 7.53(\mathrm{t}, J=6.4 \mathrm{~Hz}, 1 \mathrm{H}), 7.35-7.47(\mathrm{~m}, 4 \mathrm{H})$, 7.00-7.11 (m, 4H), 6.85-6.93 (m, 3H), 6.71-6.74 (m, 2H), 6.15-6.21 (m, 3H), $6.02(\mathrm{~d}, J=6.6 \mathrm{~Hz}, 1 \mathrm{H}), 5.19(\mathrm{dd}, J=$ $\left.16.5 \mathrm{~Hz}, 2 \mathrm{H},-\mathrm{CH}_{2}\right) .{ }^{13} \mathrm{C}$ NMR $\left(d_{6}-\mathrm{DMSO}\right): \delta(\mathrm{ppm})=188.8$, $167.5,166.5$, 164.4, 154.2, 153.9, 149.5, 149.4, 148.7, 144.4, $143.0,141.9,138.8,137.7,135.5,135.3,131.9,130.5,130.3$, 130.2 , 129.7, 128.7, 128.1, 127.1, 125.3, 125.1, 124.9, 124.6, $124.0,123.4,123.1,121.1,120.3,120.1,117.5,114.3$, 113.4, 112.8, 49.9. Found: C, 53.49; H, 3.67; N, 7.78\%. $\mathrm{C}_{41} \mathrm{H}_{31} \mathrm{~N}_{5} \mathrm{PF}_{6} \mathrm{Ir} \cdot 0.5 \mathrm{CH}_{3} \mathrm{CN}$ requires C, 53.02; H, 3.44; N, 8.10\%.

\section{Acknowledgements}

This work has been supported by the Australian Research Council (FT100100646, LE120100213, DP150102741). The Victorian Partnership for Advanced Computing (VPAC), the National Computational Infrastructure National Facility (NCI-NF) and La Trobe University are acknowledged for substantial computing resources.

\section{Notes and references}

1 L. Mercs and M. Albrecht, Chem. Soc. Rev., 2010, 39, 19031912.

2 Y. Cui, Y. Yue, G. Qian and B. Chen, Chem. Rev., 2012, 112, 1126-1162.
3 R. Visbal and M. C. Gimeno, Chem. Soc. Rev., 2014, 43, 3551-3574.

4 S. Bellemin-Laponnaz and S. Dagorne, Chem. Rev., 2014, 114, 8747-8774.

5 K. Matsumoto, N. Matsumoto, A. Ishii, T. Tsukuda, M. Hasegawa and T. Tsubomura, Dalton Trans., 2009, 67956801.

6 V. J. Catalano, L. B. Munro, C. E. Strasser and A. F. Samin, Inorg. Chem., 2011, 50, 8465-8476.

7 X. Zhang, S. Gu, Q. Xia and W. Chen, J. Organomet. Chem., 2009, 694, 2359-2367.

8 A. Poethig and T. Strassner, Organometallics, 2011, 30, 6674-6684.

9 P. J. Barnard, M. V. Baker, S. J. Berners-Price, B. W. Skelton and A. H. White, Dalton Trans., 2004, 1038-1047.

10 V. J. Catalano and A. O. Etogo, J. Organomet. Chem., 2005, 690, 6041-6050.

11 P. J. Barnard, L. E. Wedlock, M. V. Baker, S. J. BernersPrice, D. A. Joyce, B. W. Skelton and J. H. Steer, Angew. Chem., Int. Ed., 2006, 45, 5966-5970.

12 F.-F. Hung, W.-P. To, J.-J. Zhang, C. Ma, W.-Y. Wong and C.-M. Che, Chem. - Eur. J., 2014, 20, 8604-8614.

13 Q.-X. Liu, F.-B. Xu, Q.-S. Li, H.-B. Song and Z.-Z. Zhang, Organometallics, 2004, 23, 610-614.

14 Q.-X. Liu, H.-B. Song, F.-B. Xu, Q.-S. Li, X.-S. Zeng, X.-B. Leng and Z.-Z. Zhang, Polyhedron, 2003, 22, 1515-1521.

15 Y. Unger, D. Meyer and T. Strassner, Dalton Trans., 2010, 39, 4295-4301.

16 Y. Unger, D. Meyer, O. Molt, C. Schildknecht, I. Münster, G. Wagenblast and T. Strassner, Angew. Chem., Int. Ed., 2010, 49, 10214-10216.

17 R. Wai-Yin Sun, A. Lok-Fung Chow, X.-H. Li, J. J. Yan, S. Sin-Yin Chui and C.-M. Che, Chem. Sci., 2011, 2, 728736.

18 F. Zhang, L. Duan, J. Qiao, G. Dong, L. Wang and Y. Qiu, Org. Electron., 2012, 13, 1277-1288.

19 F. Kessler, R. D. Costa, D. Di Censo, R. Scopelliti, E. Orti, H. J. Bolink, S. Meier, W. Sarfert, M. Gratzel, M. K. Nazeeruddin and E. Baranoff, Dalton Trans., 2012, 41, 180-191.

20 F. Monti, F. Kessler, M. Delgado, J. Frey, F. Bazzanini, G. Accorsi, N. Armaroli, H. J. Bolink, E. Ortí, R. Scopelliti, M. K. Nazeeruddin and E. Baranoff, Inorg. Chem., 2013, 52, 10292-10305.

21 Y. Zhou, J. Jia, W. Li, H. Fei and M. Zhou, Chem. Commun., 2013, 49, 3230-3232.

22 S. U. Son, K. H. Park, Y.-S. Lee, B. Y. Kim, C. H. Choi, M. S. Lah, Y. H. Jang, D.-J. Jang and Y. K. Chung, Inorg. Chem., 2004, 43, 6896-6898.

23 G. Duan and V. W.-W. Yam, Chem. - Eur. J., 2010, 16, 12642-12649.

24 J. Dinda, S. Liatard, J. Chauvin, D. Jouvenot and F. Loiseau, Dalton Trans., 2011, 40, 3683-3688.

25 D. G. Brown, N. Sanguantrakun, B. Schulze, U. S. Schubert and C. P. Berlinguette, J. Am. Chem. Soc., 2012, 134, 1235412357. 
26 H.-J. Park, S. Yoo, I.-S. Shin, Y. K. Chung and J. Kim, Electroanalysis, 2013, 25, 1111-1115.

27 V. Leigh, W. Ghattas, R. Lalrempuia, H. Muller-Bunz, M. T. Pryce and M. Albrecht, Inorg. Chem., 2013, 52, 53955402.

28 L.-H. Chung, S.-C. Chan, W.-C. Lee and C.-Y. Wong, Inorg. Chem., 2012, 51, 8693-8703.

29 L. A. Casson, S. Muzzioli, P. Raiteri, B. W. Skelton, S. Stagni, M. Massi and D. H. Brown, Dalton Trans., 2011, 40, 11960-11967.

30 X.-W. Li, H.-Y. Li, G.-F. Wang, F. Chen, Y.-Z. Li, X.-T. Chen, Y.-X. Zheng and Z.-L. Xue, Organometallics, 2012, 31, 38293835.

31 C. Romain, S. Choua, J.-P. Collin, M. Heinrich, C. Bailly, L. Karmazin-Brelot, S. Bellemin-Laponnaz and S. Dagorne, Inorg. Chem., 2014, 53, 7371-7376.

32 G. J. Barbante, P. S. Francis, C. F. Hogan, P. R. Kheradmand, D. J. D. Wilson and P. J. Barnard, Inorg. Chem., 2013, 52, 7448-7459.

33 B. D. Stringer, L. M. Quan, P. J. Barnard, D. J. D. Wilson and C. F. Hogan, Organometallics, 2014, 33, 48604872.

34 M. M. Richter, Chem. Rev., 2004, 104, 3003-3036.

35 B. A. Gorman, P. S. Francis and N. W. Barnett, Analyst, 2006, 131, 616-639.

36 W. Miao, Chem. Rev., 2008, 108, 2506-2553.

37 X. Zhou, D. Zhu, Y. Liao, W. Liu, H. Liu, Z. Ma and D. Xing, Nat. Protoc., 2014, 9, 1146-1159.

38 G. J. Barbante, C. F. Hogan and A. B. Hughes, J. Solid State Electrochem., 2009, 13, 599-608.

39 T. Joshi, G. J. Barbante, P. S. Francis, C. F. Hogan, A. M. Bond, G. Gasser and L. Spiccia, Inorg. Chem., 2012, 51, 3302-3315.

40 T. Joshi, G. J. Barbante, P. S. Francis, C. F. Hogan, A. M. Bond and L. Spiccia, Inorg. Chem., 2011, 50, 1217212183.

41 E. F. Reid, V. C. Cook, D. J. D. Wilson and C. F. Hogan, Chem. - Eur. J., 2013, 19, 15907-15917.

42 R. V. Kiran, C. F. Hogan, B. D. James and D. J. D. Wilson, Eur. J. Inorg. Chem., 2011, 4816-4825.

43 E. H. Doeven, E. M. Zammit, G. J. Barbante, C. F. Hogan, N. W. Barnett and P. S. Francis, Angew. Chem., Int. Ed., 2012, 51, 4354-4357.

44 E. H. Doeven, E. M. Zammit, G. J. Barbante, P. S. Francis, N. W. Barnett and C. F. Hogan, Chem. Sci., 2013, 4, 977982.

45 G. J. Barbante, N. Kebede, C. M. Hindson, E. H. Doeven, E. M. Zammit, G. R. Hanson, C. F. Hogan and P. S. Francis, Chem. - Eur. J., 2014, 20, 14026-14031.

46 E. Kerr, E. H. Doeven, G. J. Barbante, C. F. Hogan, D. Bower, P. S. Donnelly, T. Connell and P. S. Francis, Chem. Sci., 2015, 6, 472-479.

47 A. Kapturkiewicz and G. Angulo, Dalton Trans., 2003, 39073913.

48 F. Zhang, L. Duan, J. Qiao, G. Dong, L. Wang and Y. Qiu, Org. Electron., 2012, 13, 2442-2449.
49 C.-H. Chien, S. Fujita, S. Yamoto, T. Hara, T. Yamagata, M. Watanabe and K. Mashima, Dalton Trans., 2008, 916923.

50 A. Sinha, S. M. Wahidur Rahaman, M. Sarkar, B. Saha, P. Daw and J. K. Bera, Inorg. Chem., 2009, 48, 11114-11122.

51 L. Farrugia, J. Appl. Crystallogr., 1997, 30, 565.

52 T. Sajoto, P. I. Djurovich, A. Tamayo, M. Yousufuddin, R. Bau, M. E. Thompson, R. J. Holmes and S. R. Forrest, Inorg. Chem., 2005, 44, 7992-8003.

53 R. D. Costa, R. Casillas and J. Cano, J. Phys. Chem. C, 2013, 117, 8545-8555.

54 A. B. Tamayo, B. D. Alleyne, P. I. Djurovich, S. Lamansky, I. Tsyba, N. N. Ho, R. Bau and M. E. Thompson, J. Am. Chem. Soc., 2003, 125, 7377-7387.

55 M. Mydlak, C. Bizzarri, D. Hartmann, W. Sarfert, G. Schmid and L. De Cola, Adv. Funct. Mater., 2010, 20, 1812-1820.

56 T. Sajoto, P. I. Djurovich, A. B. Tamayo, J. Oxgaard, W. A. Goddard and M. E. Thompson, J. Am. Chem. Soc., 2009, 131, 9813-9822.

57 W. Miao, J.-P. Choi and A. J. Bard, J. Am. Chem. Soc., 2002, 124, 14478-14485.

58 Y. Cheng, H.-J. Xu, J.-F. Sun, Y.-Z. Li, X.-T. Chen and Z.-L. Xue, Dalton Trans., 2009, 7132-7140.

59 W. Ghattas, H. Müller-Bunz and M. Albrecht, Organometallics, 2010, 29, 6782-6789.

60 J. J. Concepcion, J. W. Jurss, M. R. Norris, Z. Chen, J. L. Templeton and T. J. Meyer, Inorg. Chem., 2010, 49, 1277-1279.

61 H.-S. Chen, W.-C. Chang, C. Su, T.-Y. Li, N.-M. Hsu, Y. S. Tingare, C.-Y. Li, J.-H. Shie and W.-R. Li, Dalton Trans., 2011, 40, 6765-6770.

62 G. Sheldrick, Acta Crystallogr., Sect. A: Found. Crystallogr., 2008, 64, 112-122.

63 O. V. Dolomanov, L. J. Bourhis, R. J. Gildea, J. A. K. Howard and H. Puschmann, J. Appl. Crystallogr., 2009, 42, 339-341.

64 M. J. Frisch, G. W. Trucks, H. B. Schlegel, G. E. Scuseria, M. A. Robb, J. R. Cheeseman, G. Scalmani, V. Barone, B. Mennucci, G. A. Petersson, H. Nakatsuji, M. Caricato, X. Li, H. P. Hratchian, A. F. Izmaylov, J. Bloino, G. Zheng, J. L. Sonnenberg, M. Hada, M. Ehara, K. Toyota, R. Fukuda, J. Hasegawa, M. Ishida, T. Nakajima, Y. Honda, O. Kitao, H. Nakai, T. Vreven, J. J. A. Montgomery, J. E. Peralta, F. Ogliaro, M. Bearpark, J. J. Heyd, E. Brothers, K. N. Kudin, V. N. Staroverov, R. Kobayashi, J. Normand, K. Raghavachari, A. Rendell, J. C. Burant, S. S. Iyengar, J. Tomasi, M. Cossi, N. Rega, J. M. Millam, M. Klene, J. E. Knox, J. B. Cross, V. Bakken, C. Adamo, J. Jaramillo, R. Gomperts, R. E. Stratmann, O. Yazyev, A. J. Austin, R. Cammi, C. Pomelli, J. W. Ochterski, R. L. Martin, K. Morokuma, V. G. Zakrzewski, G. A. Voth, P. Salvador, J. J. Dannenberg, S. Dapprich, A. D. Daniels, Ö. Farkas, J. B. Foresman, J. V. Ortiz, J. Cioslowski and D. J. Fox, Gaussian 09 rev. D.01, Gaussian Inc., Wallingford CT, 2009.

65 A. D. Becke, Phys. Rev. A: Gen. Phys., 1988, 38, 3098-3100. 66 A. D. Becke, J. Chem. Phys., 1993, 98, 5648-5652. 
67 C. Lee, W. Yang and R. G. Parr, Phys. Rev. B: Condens. Matter, 1988, 37, 785-789.

68 C. Adamo and V. Barone, J. Chem. Phys., 1998, 108, 664675.

69 J. P. Perdew, in Electronic Structure of Solids '91, ed. P. Ziesche and H. Eschrig, Akademie Verlag, Berlin, 1991, pp. 11-20.

70 W. J. Hehre, R. Ditchfield and J. A. Pople, J. Chem. Phys., 1972, 56, 2257-2261.

71 P. C. Hariharan and J. A. Pople, Theor. Chim. Acta, 1973, 28, 213-222.

72 T. Clark, J. Chandrasekhar, G. W. Spitznagel and P. v. R. Schleyer, J. Comput. Chem., 1983, 4, 294-301.

73 T. H. Dunning Jr. and P. J. Hay, in Modern Theoretical Chemistry, ed. H. F. Schaefer, III Plenum, New York, 1976, vol. 3, pp. 1-28.

74 D. Andrae, U. Haeussermann, M. Dolg, H. Stoll and H. Preuss, Theor. Chim. Acta, 1990, 77, 123-141.
75 J. Lin, K. Wu and M. Zhang, J. Comput. Chem., 2009, 30, 2056-2063.

76 G. J. Barbante, C. F. Hogan, D. J. D. Wilson, N. A. Lewcenko, F. M. Pfeffer, N. W. Barnett and P. S. Francis, Analyst, 2011, 136, 1329-1338.

77 A. Schaefer, H. Horn and R. Ahlrichs, J. Chem. Phys., 1992, 97, 2571-2517.

78 J. Tomasi, B. Mennucci and R. Cammi, Chem. Rev., 2005, 105, 2999-3093.

79 R. E. Stratmann, G. E. Scuseria and M. J. Frisch, J. Chem. Phys., 1998, 109, 8218-8224.

80 S. I. Gorelsky, AOMix: Program for Molecular Orbital Analysis, Version 6.46, University of Ottawa, http://www.sg-chem.net/, 2010.

81 E. D. Glendening, J. K. Badenhoop, A. E. Reed, J. E. Carpenter, J. A. Bohmann, C. M. Morales and F. Weinhold, NBO 5.9, Theoretical Chemistry Institute, University of Wisconsin, Madison, 2001. 